\title{
1. ПЕРЕДМОВА
}

1. ПЕРЕДМОВА

3

2. КОСМІЧНА ФИЛОСОФІЯ І НАУКОВО-ТЕХНІЧН ЦДЕ MOHЕРА КОСМОНАВТИКИ

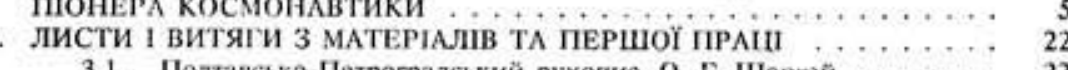

3.1. Полтавсько-Петроградський рухопис, О. Г. Шаргей ....... 22

3.2. Витяги 3 першой передмови Ю. В. Кондратюка до книги Завояованки космічного просторуь ... . . . . . . . 29

3.3. Витяги з другоі передмови автора до книги

¿авоювання міжыланстних просторіре ................

3.4. Напис на титульнму аркуші хниги «авоюпання

міжлтанетних просторіщ, надісланої К. Е. Шіолковскому

(1 кеартал 1929 р): ...................... 32

3.5. Лист до науконого редактора В. П. Ветчинкіна

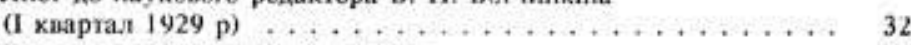

3.6. Лист до професоран М. О. Риніна _............. 32

3.7. Рядки 3 листа К. Е. Шілковському ... . . . . . . . . . 37

3.8. Дані 3 анкети для заарештованих $\mathrm{i}$ затриманих з зарахуваниям за одпу $(30.07 .1930$ р.) .................. 37

3.9. Витяги з протоколів допиту (1930 р.) ............ 38

3.10. Уривки 3 технічиих довідок до проекту вітроелектроустановок (1932-1938 pp.)

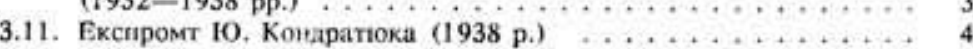

3.12. Замітка $(20.06 .1938$ р.) ... . . . . . . . . . . . . 42

3.13. Відиовідь на лист О. М. Горчаконої ...

3.14. Листівка Ю. В. Кондратюка до Г. П. Плетньової . . . . . . . 42

4. ПЕРЕЛІК ОПУБЛККОВАНИХ І РУКОПИСНИХ ПРАШЬ

Ю. В. КОНДРАТІОКА (О. Г. ШАРГЕЯ) $\ldots \ldots \ldots \ldots \ldots \ldots \ldots \ldots . \ldots 43$

$4.1 . \quad$ Опубліковані твори ................. ${ }_{43}$

4.2. Рукописи, мхі зберетлися ................. 43

5. СТОРНКИ ЖИТТЯ ГЕНІЯ (Біографія

10. В. Кондрапока - О. Г. Шаргея) ... . . . . . . . . . . .

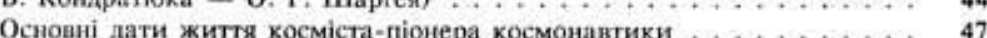

6. ЛІТРАТУРА ..............................

(C) А. П. Завалішнн, А. В. Даценко, 1997

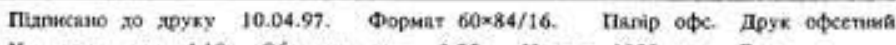

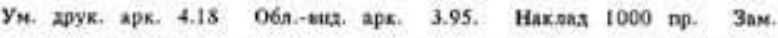

| ікаво відзначити, що саме у 1997 році багатьом космістам виповнилася від дня народження кількість років, кратна 10: 140 років - К. Е. Ціолковському, 110 років - Ф. А. Цандеру, 100 років - О. Л. Чижевському, 90 років - С. П. Корольвопу.

y цъому $ж$ році 21 чсрвня ниповнюсться 100 років від дня народження одного 3 піонсрів космізму і провидця зсмної космічноі ери людства - Олександра Гнатовича Шаргея, який протягом багатьох років переховувався під чужим прізвицем Юрія Васильовича Кондратюка. Не вчинивши ніякого злочину проти людства і свого народу, він в умовах громадянської війни колишньої Російської імперії був змушений взяти чуже прізвище і потім, під час сталінських репресій, не повертатися до свого справжнього імені.

Під іменем Кондратюка О. Г. Шаргей увійшов у історію космонавтики поряд 3 К. Е. Ціолковським, Ф. А. Цанлером та іншими. Випереджаючі свій час погляди на життя, проекти, прозорливість, сміливість, і неординарні рішення дозволяють назвати О. Шаргея (Ю. Кондратюка) талановитим вченим, філософом, блискучим інженером, що збагатив спадщину світовоі філософії, науки та техніки.

У науково-технічній творчості Кондратюка виділяються такі три основні напрямки: дослідження і освосння космічного простору, вітроенсргетика, будівництво і механізація зерносховищ.

Найяскравішим витвором наукового таланту Конаратюка у «некосмічній» сфері став проскт Кримської вітроелектростанціі, яку можна вважати «прообразом» Останкінської. Тут вперше застосований для вежі попередньо напружений залізобстон, а методику розрахунку вежі розробив М. В. Нікітін разом 3 Ю. В. Кондратюком. Не дивлячись на те, шо проект КримВЕС не був здійснений, багато рішень, знайдених при роботі над ним, використовуються і зараз, і не лише в Останкіно.

Серед багатьох знаменитих нікітінських праць, мабуть, найвідоміша - Останкінська телевежа у Москві - пам'ятник мріі Ю. В. Кондратюка і М. В. Нікітіна, іх спільній мрії про велику електростанцію вітру, так і не зведеній над Ай-Петрі.

у галузі сільськогосподарського будівництва необхідно відмітити ряд його винаходів з механізації вантажно-розвантажувальних робіт на елеваторах і зерносховишах. Один з них спеціалісти 
назвали іменем автора «ківш Кондратюка» (патент від 1929 р.), а прийнятий Кондратюком принцип конструкції зберігся і у наступних модифікаціях інших винаходів. Особливістю цього ковша було тс, що замість суцільної передньої стінки використані декілька нахилених пластин 3 проміжками. Це забезпечило повніше завантаження ковша зерном і легше його розвантаження. Представляють інтерес оригінальна конструкція найбільшого у світі дерсвяного зерносховища, збудованого без цвяхів, баштового залізобетонного копра, рухомої опалубки. До речі, цю роботу Ю. Кондратюк виконував з участю М. В. Нікітіна.

Грандіозність і незвичайність характеризували усе творче життя Юрія Васильовича - будівництво найбільшого зерносховища на 10000 тонн, проект найбільшої у світі вітроелектростанції на 10000 кіловат тощо.

Але все ж справою життя Ю. В. Кондратюка була космонавтика. Саме у цьому найповніше розкрився його творчий геній: розробка філософських поглядів на практичну космонавтику і ряд інших космічних проектів (потужних ракет-носіїв для польоту на Місяць і планети Сонячної системи, орбітальних науково-дослідних комплексів, транспортних кораблів постачання, міжпланетних проміжних баз, дзеркал-відбивачів, за допомогою яких використовусться енергія сонячного проміння, котра утилізусться поза земною атмосферою для глобальної зміни клімату цілих континентів $\mathrm{i}$ видозміни планети Земля).

Уперше у світі і в Україні зібрані перша праця Ю. В. Кондратюка, частина його листів і витягів з праць, перелік праць вченого, досить докладний опис його життя та діяльності.

Водночас повідомлясмо, що перший космічний рукопис «Полтавсько-петроградський рукопис», розпочатий сімнадцятирічним полтавським гімназистом $\mathrm{i}$ завершений двадцятирічним петроградським прапорщиком О. Г. Шаргесм можна розглядати як завершену наукову працю. Робота, написана у період 1914-1917 pp., це чотири учнівські зошити, прошиті невмілою рукою.

Ці попередні замітки у формі щоденника, в яких юний автор викладає основи майбутніх геніальних рішень, стали основою для подальшої наукової розробки автором космічної тематики. Даний рукопис вочевидь не передбачався для публікації, проте у ньому висунуті ідеї, які здійснилися через сорок років.

Оскільки упорядники книги не мали оригіналів чи копій «Полтавсько-петроградського рукопису», тому скористалися матеріалами, які видав брат Ю. В. Кондратюка Анатолій Васильович Даценко, і замітками, зробленими ним під час перебування у 1984 році в Інституті історії і природознавства АН СРСР.

\section{2. КОСМІЧНА ФІЛОСОФІЯ \\ I НАУКОВО-ТЕХНІЧНІ ІДЕЇ ПІОНЕРА КОСМОНАВТИКИ}

олосальний обсяг нових знань і понять внесли у свідомість людства засновники космізму В. І. Вернадський, Р. Х. Годдард, Ф. А. Цандер, Р. А. Ш. ЕноПельті, М. Ф. Федоров, К. Е. Ціолковський, О. Л. Чижевський та інші. Це був стрибок, чкий можна порівняти хіба шо 3 коперниковським персворотом у світогляді. Ракета, відома 3 найдавніших часів, набувала нових якостей $\mathrm{i}$ розгортала перед людством нові можливості. До цісї плсяди вчсних налсжить і Юрій Кондратюк провидець «земної» космічної ери людства планети Земля, дивовижний за широтою діапазону свосї творчості самобутній вчсний, ім'я якого в історії космічної філософіï, науки і техніки стоїть поряд 3 іменем К. Е. Ціолковського.

Дещо абсолютувавши земні функції людини, Ю. В. Кондратюк, Ф. А. Цандер, К. Е. Ціолковський незалежно один від одного прийшли до думки освосння i обживання позаземного простору, а також обгрунтували і розвинули думки про дослідження і використання космічного простору на благо людства. Генетичною рисою космічної філософії с утвердження ідеї активної еволюції. Потрібен новий, свідомий етап розвитку світу, коли людство, керуючись Розумом і моральними почуттями, спрямовус розвиток природи, Всесвіту. у цьому важливому твердженні космічної філософії накреслені перспективи сволюції Світу і визначсна роль у цьому процесі Людини і Людства. (Досить стисло вихідні ідеї космічної філософії можна окреслити так: органічно єдиний світ потребус становлення цільної людини, якій у процесі оволодіння досвідом відкриються знання про Буття, Космос, Всесвіт, а у результаті визначаться грандіозні перспективи натхнснної еволюціі.)

у цьому і полягає якісна відміна іхніх космічних філософій від філософій усіх попередніх і наступних прихильників космізму.

Прямуючи до однісї мети (освосння космічного простору на благо людства), вчені-космісти виходили із основного бажання здійснити міжпланетний політ із людьми, потім прийшли до висновку, що засобом його здійснення могла бути тільки ракета. В цьому усі трос були едині. Проте шляхи і способи в досягненні мети людства кожен 3 них пропонував свої. I тому на світ з'явилися три відалуження космічної філософії: 
1. «Небеснар - К. Е. Ціолковського. «Земля - колиска РОЗУМУ, але не можна вічно жити у колисці.» А відтак, «людство в погоні за світлом і простором спочатку нерішуче потрапить за межу атмосфери, а потім заволодіс усім навколосонячним простором, створивши у ньому штучні поселення - еефірні міста», «ефірні острови».

2. «Планетна» - Ф. А. Цандера. «Хто не здіймав в ясну, зоряну ніч свій погляд на небо, на якому сяють мільйони зірок i не думав про те, що навколо них на планетах повинні жити інші людства, які у культурі на багато тисяч років випередили нас! Які незчисленні цінності доставлені були б на Землю, якби вдалось перелетіти туди!»

3. «Земна" - Ю. В. Кондратюка. «Торкнусь основного питання цісї роботи, зовсім не висвітленого у первісному викладі питання про очікувані результати для людства від виходу його в міжпланетні простори. Без сумніву, ще довгий час вкладення коштів у покращення життсвих умов на планеті буде більш рентабельним, ніж освоєння колоній поза іi межами - потрібно не забувати, що в порівняні з загальною поверхнею нашої планети лише незначна частина ії заселена і експлуатусться повністю...»

К. Е. Ціолковський виходив 3 того, що мета пізнання і діяльності - щастя людини. «Нескінченний розвиток і вдосконалення», на його думку, на Землі не досяжні, тому тільки пізнавши закони Всесвіту i створивши засоби виходу за межі планети, людство здобуло б свободу переміщення у космосі, інші джерела енергії i досягло б свосї мети.

3 погляду Ф. А. Цандера потрібно зразу ж летіти на Марс, для того щоб високорозвинену в економічному, технологічному, технічному і соціальному відношеннях марсіанську цивілізацію використати для перебудови діяльності землян.

Ю. В. Кондратюк бачив навколоземний космос, міжпланетний простір як поле мирної діяльності жителів нашої Землі. Він прекрасно розумів, що нам, землянам, мимоволі доведеться створювати космічне виробництво матеріальних благ, нові, можливі лише в умовах невагомості і глибокого вакууму технологіі, освоювати території, природні багатства астероїдів, Місяця, планет Сонячної системи, максимально використовувати променеву енергію Сонця. Про те, що мирна діяльність жителів Землі у космосі не така вже і далека, молодий вчений писав у 1919 році у другому варіанті рукопису «Тим, хто буде читати, щоб будувати»: «Насамперед, щоб питання цісї праці не лякало Вас і не відхиляло від думки про можливість здійснення, весь час твердо памятайте, що
3 теоретичного боку політ на ракеті у всесвіт не $є$ нічим дивовижним і неймовірним...»

Таким чином, О. Г. Шаргей вважав, шо створена теоретична база вже достатня для початку сксперимснтування. Він намічає наступні заходи, що мають завершитися експериментом:

1 - випробувати дію засобів для підйому в атмосферу:

2 - політ не дужс далеко від Землі - на декілька тисяч верст;

3 - політ на Місяць без зупинки на ньому, власне політ навколо Місяця;

4 - політ на Місяць із зупинкою.

Він з дивовижною прозорливістю передбачав ту користь, яку в недалекому майбутньому принесе людству освоєння міжпланетного простору, зокрема ближнього, навколоземного космосу: «Подивимось на проблему виходу людини у міжпланетні простори 3 сьогоднішнього погляду: чого ми можемо конкретно чекати в найближчі десятиріччя, рахуючи від першого польоту з Землі...»

На думку Кондратюка, це:

- збагачення наукових знань 3 «відповідним відображенням цього у техніці»;

- можливість отримання на інших планетах цінних речовин, «sкі відсутні або занадто рідко зустрічаються на земній поверхні»;

- еінші дари..., яких може i не бути, наприклад результати спілкування 3 імовірним органічним світом Марса...»;

- «безперечна можливість для людства оволодіти ресурсами, за допомогою яких можна буде докорінно покрашити умови існування на земній поверхні»;

- «Тльки за можливості у найближчому ж майбутньому почати по-справжньому господарювати на нашій планеті і потрібно бачити основне велике значення для неї у завоюванні просторів Сонячної системи».

Крім того, Ю. В. Кондратюк значною мірою випередив обговорення тих проблем, які ми зараз відносимо до глобальних, особливо пов'язаних з екологією. Ще не відчуваючи глобальних наслідків розвитку техніки і виробництва, саме Ю. В. Кондратюк, а також K. Е. Ціолковський запропонували один із можливих шляхів запобігання загибелі людства - освосння космічного простору 3 винесенням у нього виробництва.

Наочно, доступно і точно про філософію трьох засновників космізму сказав колишній інженер - конструктор НВО ім. Лавочкіна, дослідник життя і діяльності Шаргея-Кондратюка Б. 1. Романенко: «Таким чином, «планетна» космічна філософія Цандера мертва, «небесна» ж Ціолковського передчасна, а «зем- 
ній Кондратюка треба дати «зелену вулицю». Розумного життя на Марсі не виявлено (польоти людини по «планетній філософії), міжпланстні польоти людини («небесна філософія») через неспроможність економіки світу не можуть привернути для здійснення всликі матеріальні та інтелектуальні ресурси, в той час коли на Землі і у близькому космосі вслика кількість невідкладних справ, які реально можуть стати економічно рентабельними. Ставлення людства до природи як до «рабині», посднане 3 дегуманізацісю розвитку техніки, вжс привело до глобальної екологічної кризи, яка загрожус планетарною катастрофою. Зараз перед нами настало завдання збереження природи Землі, що означае перехід на такі способи раціонального природокористування, які б не загрожували самогубством людині.

Один із напрямків розвитку - вихід техніки і виробництва у космос, індустріалізація останнюого 3 тим, щоб послабити антропогенний тиск на природу, особливо на біосферу Землі - певна річ, його індустріалізація в максимально екологізованому варіанті.

Другий - використання сонячної енергіï. Створення космічних сонячних електростанцій і спорудження космічних екраніввідбивачів сонячного проміння, дасть змогу вже в недалекому майбутньому освітлювати міста і промислові регіони, сільськогосподарські угідая тощо. Покращивши цим екологію і зберігаючи енергоносії Землі (вугілля, нафту, газ, сланщі) для наступних поколінь планети, 3 метою використання іх для приготування іжі, ліків, виробництва одягу, органічних добрив для ланів і створення нових конструкційних матеріалів...

Освосння фприземного» космосу за Ю. В. Кондратюком - де освосння нового середовища, відмінного від того, до якого людина звикла за час еволюції на Землі. Тут важливо відмітити принципові зрушення у космічному способі мислення - від споглядальноастрономічного здійснюеться перехід до екологічно-астронавтичноro. Цей перехід став вирішальним для виникнення теоретичної космонавтики. Екологічна обумовленність виходу людства за межі планети була лейтмотивом творчості піонера космонавтики, і усі інші соціальні ефекти від розвитку космонавтики були тісно пов'язані 3 екологічними вигодами освосння нового для людини середовища мешкання.

Слід відзначити, що Ю. В. Кондратюк ніде у своїх роботах детально не обтоворював можливість міжзоряного польоту, і нам важко не визнати це цілком виправданим, оскільки враховуючи велику відстань до зірок і занадто малу швидкість ракети, навіть зараз такі проекти виглядають фантастично. Однак ідея досягнення людиною поверхні багатьох небесних тіл у межах Сонячної систе- ми ним була сформульована. Вчений писав, що з погляду енергетики вигіднішс використовувати не весь снаряд при польоті до планети, а «пустити його супутником, i самому 3 частиною снаряда, нсобхідною для зупинки на планеті і зворотного присднання до снаряда, здійснити цю зупинку...» на планеті. Він вбачав, шо досягнсння найвіддаленіших об'єктів буде не важчим від запуску супутників Землі, якщо досконало розробити програму польоту 3 використанням проміжних планет і штучно створенг. баз. Ним була запропонована оптимістична гіпотеза, що здійснення проекту освосння міжланетного простору «цілком можливе i сьогодні для нашої сучасної техніки після серії попередніх експериментів, які не викликають трудношів, починаючи і закінчуючи польотом на Місяць і Марс, вимагало б меншої кількості матеріальних коштів, ніж спорудження одного дредноута...»

Актуальним і сьогодні $є$ припущення Ю. В. Кондратюка про те, що в багатьох випадках в якості проміжної бази слід використовувати Місяць і штучні супутники іншої планети. Теорії проміжних баз він присвятив багато праць $\mathbf{i}$ довів, що спуск на плансту вигідніше здійснювати за допомогою спеціального посадочного модуля, який відділясться від бази і повертається до неї. 1 про це писав наступне:

«Чим залітати кожен раз на Землю, вигідніше мати бази з малим потенціалом тяжіння (на саморобних супутниках Місяця, наприклад, або на самому Місяці). А на рухомих саморобних базах потрібно зберігати запаси активних речовин (палива, енергіi), прилади, інструменти, іжу...

фДоцільно чинити так: спочатку відправляти з Землі на базу 3 запасами, але без людей..., а потім вже відправляти снаряд 3 людьми; залетівши на базу, забирають потрібне і летять далі, а база залишасться літати навколо Землі. На зворотному шляху знову забирають на ній запаси і повертаються на Землю. Такий спосіб зручний тим, що, відправляючи головну частину людей, ми не обтяжені у величині прискорення i можемо навіть використати просту гармату».

На базу-супутник Місяця \&... бажано б доставити снаряд і всі предмети, які спроможні переносити без шкоди для себе прискорення у декілька тисяч метрів за секунду (усі, крім тонких приладів) ... ракетно-артилерійським способом окремо від людини», оскільки «людина зовсім неспроможна перенести артилерійські прискорення».

«Ракети 3 Землі будуть направлятися лише для постачання на базу i зміни екіпажів. Якщо ж вдасться ракетно-артилерійське постачання, то ми отримаємо економію приблизно $50 \%$ \%. 
Заглядаючи далеко наперед, «...коли буде великий рух з Землі у міжзоряний простір», пропонує для збереження кількості палива на борту еснаряда» надавати йому початкову швидкість наземним устаткуванням» (наприклад, електричною гарматою).

Вчений геніально просто розв'язує задачу, яка не була вирішена до нього жодним із співвітчизників, теоретиків міжпланетних мандрівок. Йдеться аро висадку людини на небесне тіло, що має значнс поле тяжіння. О. Г. Шаргей розуміє, що для посадки всьопо літального апарата на це тіло, а потім для зльоту з нього потрібна буде величезна кількість палива, і приходить до висновку, що можливо: «Щоб не використовувати великої кількості активноі речовини, можна не зупиняти весь снаряд, а лише зменшити його швидкість настільки, наскільки потрібно, щоб він рівномірно рухався вздовж кола якомога ближче до тіла, на якому повинна бути зроблена зупинка. Після цього виділити 3 нього неактивну частину 3 такою кількістю активної речовини, яка потрібна для зупинки неактивної частини і для того, шоб вона потім змогла наздогнати, з'сднатись з іншою частиною снаряду».

У свої теоретичних працях Юрій Васильович приходить до цілого ряду фундаментальних висновків, які і до теперішнього часу широко використовуються у космічній техніці. Більш того, по мірі все більшого розвитку практичних праць і вдосконалення космічноі техніки, підтверджуються висновки, зроблені ним дуже давно. Оригінальні дослідження найвигідніших програм польоту стали фундаментальними в розробці теорії освосння космічного простору і мали велике значення для майбутнього.

Багато часу приділив учений у своїй праці інженерній розробці конструкції літальних апаратів. У цьому виявились його якості механіка-практика, а також бажання довести дослідження до «робочого проекту».

Не розкриваючи детально ідеї Юрія Васильовича про засоби проникнення у космічний простір, доцільно зупинитися на його задумах.

Створення ракетно-космічної техніки Ю. В. Кондратюком задумувалось як засіб досягнення головної стратегічної цілі. 1 ось він уже обгрунтовує створення багатоступеневої ракети, в якій, відпрацювавши своє, ступені ракети («комплекси») повинні або відкидатися, або перероблятися і використовуватися як паливо: «Коли ми використасмо деяку частину активної речовини, ми кидасмо і ту посудину, у якій вона була. Тому краще, а може й необхідно, не тримати весь запас активної речовини в одній посудині, а у декількох, що прогресивно зменшуються».

Він розробив низку цікавих рішень, пов'язаних з конструкцісю ракети, розміщенням мас усередині ракети, охолодженням камери с сопла компонснтами палив, шаховим розміщснням форсунок пального і окислювача у камері двигуна, керуванням полютом ракети шляхом використання енергї струменя витікаючих газів тощо. При цьому вчений приділив особливу увагу проблсмам управління польотом. Він добре уявляв структуру керування космічним літальним апаратом, вказував, що управління польотом повинно бути автоматичним, базованим на сигналах, які знім:аються 3 двох гіроскопів із взасмно перпендикулярними векторами кінетичних моментів, що в систему керування повинні бути включені датчик наданого прискорення та інтегратор його сигналів і на іх основі слід регулювати тягу.

Ю. В. Кондратюк дає формулу польоту ракети у земному полі (виражену через теплотворну здатність палива і на основі принципу розподілу енергії обернено пропорційно масам), пропонує дві умови польоту людини у космос: 1) безпека для пасажирів, і 2) керованість. Розглядас також два головних імовірних напрямки руху - a) ракета відходить від Землі по вертикалі i б) ракета розганяеться по колу. Він присвячус багато сторінок «способам відльоту» і визначенню найоптимальніших 3 них. На сфективність роботи двигуна впливас не тільки всличина прискорення, тобто інтенсивність спалення палива, але і напрямок розгону при старті. Це виявлясться Кондратюком під час порівняння ерадіального відльоту», про який ішла мова, з «відльотом по дотичній».

Вивчення цього питання привело вченого до відкриття найбільш зручної «кривої відльоту» - кола 3 подальшим розвитком у витягнуті еліпси 3 фокусами у центрі Землі i перигесм на одній висоті. Доповнена теоріями багатоступеневої ракети і проміжних баз, розробка найбільщ вигідних траекторій і режимів роботи двигуна і стала тісю галуззю астронавтики, у якій Кондратюк виявив свій талант найяскравіше.

К. Е. Ціолковським було запропоновано дуже цікаве вирішення задачі про спуск ракети на Землю майже без затрат палива. у цьому випадку ракета, входячи до атмосфери Землі, гальмуе, здійснюючи рухи по орбіті навколо земної кулі, за проміжок часу, достатній для того, щоб згасити величезні швидкості входу, при збереженні допустимих для ракети режимів перевантажень і нагріву при гальмуванні. Цю думку надалі розвинув Ю. В. Кондратюк.

Проблема спуску 3 орбіти на Землю теж була представлена ним у елементарній, фактично реалізованій формі. На його думку, спускний апарат повинен бути заекранованим теплозахисним щитом, встановленим так, щоб забезпечити при спуску більший (майже $40^{\circ}$ ) кут атаки. При цьому теплозахисний щит одночасно 
буде працювати як аеродинамічна поверхня, створюючи сили опору і бокову. Останню можна спрямовувати як вгору, так і вниз, здійснюючи оберти по крену. Вказуючи на необхідність керування за креном (а не за кутом атаки, на що наголошували Ціолковський i Цандер), Кондратюк вважав, що це необхідно, виходячи 3 міркувань теплозахисту спускного апарата.

Для гарантування безпеки на момент спуску з орбіти і на ділянці розгону ракети він розробив варіант крісла космонавтів, яке дозволяє переносити більші навантаження за рахунок індивідуальної підгонки їх по фігурі, та запропонував найбезпечіше розташування членів екіпажу при зльоті і посадці (коли діють великі прискорення) відносно напрямків руху: розташування їх в індивідуальних формах-ложементах перпендикулярно до напрямку pyxy.

Уперше було поставлено питання про створення для кожного космонавта індивідуальних ложементів і у загальному випадку про створення штучної гравітації на космічному кораблі. Кондратюк відзначав, що потрібно провести додаткове вивчення і тренування людини на «великій відцентровій машині» (центрифузі), Тим самим Кондратюк уперше поставив і розглянув питання космічної біології і медицини.

Він же запропонував використання шлюзу для сполучення 3 відкритим космосом і рекомендував «виходити 3 камери снаряда... y подібних до водолазних костюмах, маючи при собі запас повітря», тим самим мова йде про космічні скафандри, а для завершення спуску - використовувати паращут, який забезпечує, у залежності від свого розміру, спуск або всього снаряда, або одного пілота.

Для вирішення завдання забезпечення теплового режиму космічного апарата він пропонує багатостадійну екранно-вакуумну теплову ізоляцію. Ю. Кондратюк особливо підкреслював простоту і легкість такої теплової ізоляції, прекрасно розуміючи ї̈ багатоцільове призначення - служити як для збереження тепла космічного апарата, так і для захисту ві,1 перегрівання сонячним випромінюванням. Крім того, розглядаюгься ускладнення, які вносить атмосфера як при зльті, так і при поверненні на Землю; пропонує неактивну частину снаряда зробити планером, виводить формулу повернення на Землю при єаеродинамічному спуску»; вносить пропозицію про багатоцільове використання сонячного тепла, що концентрується за допомогою легких дзеркал, які розгортаються у космосі, як для потреб самого міжзоряного корабля, так і для «земної утилізації; висловлює думку про застосування дзеркал-рефлекторів өдля бездротового телеграфу», тобто передбачає ідею обладнання антени направленої дії тощо.
Майже у кожному випадку при описі елементів конструкції ракети він пропонував два або три варіанти, підкреслював необхідність подальших досліджень i, головне, експериментів і ще раз експериментів. «Тема про міжпланетний політ... заволоділа мною на тривалий час, поки не підійшов до межі, за якою подальша плідна праця неможлива без паралельних експериментів».

Можна називати ще багато проблем і запитань, відповіді на які знайшов вчений-самоук...

Уже будучи автором багатьох винаходів, Ю. В. Кондратюк познайомився $з$ працями К. Е. Ціолковського і написав йому: «Я кожен раз дивуюсь схожості нашого мислення». Про схожість думок двох великих космістів говорять наступні факти.

У передмові до книги «Завоювання міжпланетних просторів» (Новосибірськ, 1929) Ю. В. Кондратюк писав: «У 1921 році я прийшов до дуже неординарного вирішсння питання про обладнання ліній передачі з Землі у простір і назад... Вказані розділи нс увійшли у цю книгу; вони занадто близькі до робочого проскту завоювання світового простору, занадто близькі до того, щоб іх можна було 6 опублікувати, не знаючи наперед, хто $\mathrm{i}$ як цими даними скористасться».

К. Е. Ціолковський розумів, що такий геній-самородок, яким був Ю. В. Кондратюк, який у молоді роки випередив багатьох визнаних вчених світу, міг також відкрити-винайти і такий невідомий спосіб пересування у космічному просторі, який міг би дати у руки сумнівних угрупувань або окремих особистостей серйозні переваги перед природою або людством, і незадовго перед свосю смертю у бесіді з А. Л. Чижевським відмітив: «Якщо буде запропонований новий, не ракетний спосіб польоту, я його прийму!» На жаль, цей спосіб пересування не дійшов до нас, бо тоді зовсім іншим шляхом міг би піти розвиток космонавтики теоретичноі, а може і практичної.

3 високого гуманізму і почуття відповідальності перед світовим товариством, старанно продумані і обгрунтовані, близькі до реалізації ідеї з технічними рішеннями Ю. В. Кондратюк не включив у жодну з останніх своїх публікацій.

В те, що ці ідеї-рішення могли бути реаліями, вірить $\mathrm{i}$ Б. І. Романенко і закликає у своїх виступах i творах шукати ці матеріали, які були віддані вченим на збереження перед відправкою у діючу армію: «Необхідно знайти нову опору, наприклад, яке-небудь поле. Ю. В. Кондратюк придумав новий спосіб польоту у космічні простори і назад, але не опублікував цю таємницю, взяв iі до могили при обороні Москви. У теперішній час при Академії космонавтики ім. К. Е. Ціолковського (Росія) заснована премія 
імені Ю. В. Кондратюка по розробці нетрадиційних рушіїв для космонавтики, для вирішення цього завдання».

«Я думаю, що якби він (Ю. В. Кондратюк) був живий і міг працювати у галузі ракетної техніки після війни, - відзначає відомий російський вчений у галузі ракетобудування Б. В. Раушенбах, - він був би таким, як Корольов».

Тим більш:, що для космонавтики потрібна була людина з подібним світоглядом і подібним інженерним мисленням. Та С. П. Корольову потрібен був такий соратник $\mathbf{i}$ послідовник, тому він і запропонував співробітництво Юрію Васильовичу з групою по вивченню реактивних двигунів, яка знаходилася під контролем керівних органів Червоної Армії. Але не зміг Ю. В. Кондратюк прийняти подібну пропозицію, оскільки сам був недавно репресований, знаходився під контролем спецорганів і остерігався, що зясується історія його участі у білій армії і присвосння чужого імені.

Аналізуючи філософську, наукову і технічну спадщину Ю. В. Кондратюка, вчені та інженери усього світу відкривають у ній все нові і нові концепції, ідеї, грані, які раніше залишалися без уваги дослідників, тому що були не зрозумілими, або не прийшов час для їхнього втілення. Одна 3 причин цієі невичерпності спадщини вченого-самоука - це оновлення мислення, виникнення нових проблем, крізь призму яких очевидна актуальність творчості одного 3 основоположників теоретичної космонавтики.

Науково-технічні ідеї, що їх визначили Ю. В. Кондратюк, К. Е. Ціолковський, Ф. А. Цандер, С. П. Корольов незалежно один від одного, охоплюють усі розділи космічної діяльності і космічної техніки, тому, не полемізуючи про пріоритети, можна підтвердити, що вони - провидці космічної ери і першопрохідщі практичної космонавтики. I все ж:

1. Хоча розвиток практичної космонавтики у перші десятиріччя ери космосу вніс свої корективи в еекологічну картину» виходу людини у космос, проте основна ідея Юрія Васильовича про необхідність освоєння людством нового, позаземного середовища мешкання і використання була правильною.

2. Виведення основної формули польоту ракети, довсдсння необхідності застосування багатоступінчастих ракет 3 пропорційно зменшуваною вагою і об'ємом баків реалізується в усіх космічних ракетах-носіях. Сумарна маса ракети-носія після відокремлення кожного ступеня зменшується приблизно у чотири рази. Перше використання у космонавтиці 4 жовтня 1957 р. при запуску першого штучного супутника Землі. Як при запуску першого штучного супутника Землі, так i в усіх наступних космічних стартах використані також пропозиції Ю. В. Кондратюка щодо застосування гіроскопін і акселерометрів у системах керування; щодо конструкціі камери згорання і охолодження сопла двигуна компонентами палива; стосовно вертикального старту та ряд інших.

3. Зліт із Землі і посадка на Землю космічних апаратів різних космічних держав, літальні орбітальні станції типу «Салют», «Мир», «Скайлеб», «Фрідом» зі змінними екіпажами, вантажні космічні кораблі типу «Прогрес», міжпланетні проміж ні бази, посадка автоматів і пілотованих апаратів на Місяць і планети Сонячної системи, а також виконання програми «Космос - людству і плансті Земля» - все це здійснюється за Кондратюком.

4. Використання тяжіння нсбесних тіл (пертурбаційний маневр), яке запропонував Кондратюк для корекції орбіти, широко застосовується у польотах автоматичних міжпланетних станцій. Зустріч радянської міжпланетної станції «Вега» 3 кометою Галлея була здійснена за допомогою таких самих гравітаційних маневрів.

5. Пропозиція Ю. В. Кондратюка щодо використання орбітального і посадочного модулів для досягнення інших планет також широко застосовусться. Найяскравішим прикладом с політ на Місяць із зупинкою на ньому і поверненням на Землю. Першими «трасу Кондратюка освоїли Нейл Армстронг, Майкл Коллінз і Едвін Олдрін у 1969 р. 21 липня Нейл Армстронг ступив на поверхню Місяця. Потім до нього присднався Едвін Олдрін. Завершивши перебування на Місяці, місячний модуль злетів, стикувався 3 кораблем «Аполлон-11», який чекав його на навколомісячній орбіті, а 24 липня 1969 р. корабель «Аполон-11» приводнився у Тихому океані.

6. Використання скафандра типу водолазного із запасом повітря для перебування у відкритому космосі також повністю реалізовано. Що правда, при першому використанні космічного скафандра запаси повітря знаходилися на космічному кораблі «Восход». Але тоді ж була реалізована й інша пропозиція Ю. В. Кондратюка - застосування шлюзу для виходу у відкритий космос. Першим у історії людства залишив космічний корабель і через шлюз вийшов у скафандрі у відкритий космос А. А. Леонов.

7. Вказівки щодо необхідності забезпечення безпеки екіпажу при дії перевантажень і пропозиція про розміщення космонавтів у спеціальних ложементах за формою їхніх тіл були ре- 
алізовані в усіх пілотованих космічних кораблях «Восход», «Союз», «Джеміні», «Аполлон». Для кожного космонавта виготовляється персональне крісло, точно підігнане до форм його тіла. Безперечно, це призводить до необхідності перестановки крісел при поверненні 3 орбіти на іншому кораблі. Та додаткова робота окупасться підвищенням безпеки. Крім того, як і прогонував Ю. В. Кондратюк, крісло розташоване так, що прискорення втискує космонавта у нього, тобто перевантаження діс у напрямку груди - спина, оскільки в такому положенні воно легше переноситься. Тому космонавти злітають обличчям вперед (лежачи на спині), а сідають на Землю спиною вперед. Уперше ця пропозиція була застосована у космонавтиці 12 квітня 1961 року при запуску і спуску першого космонавта - Ю. О. Гагаріна.

8. 4 лютого 1993 року, перед світанком, сонячний зайчик, відбитий від плівочної парасольки діаметром двадцять метрів, розміщеної у космосі поруч з російською орбітальною станцією «Мир», пробіг через Ліон, Відень, Берн, Штутгарт, Мюнхен, Прагу, Лодзь, Брест, Гомель... «Цей експеримент став першим випадком, коли людині вдалося штучно сконцентрувати розсіяне у космічному просторі сонячне світло, яке несе невичерпні запаси енергіi» (газета «Известия», 5 лютого 1993 р). Таким чином, пропозиції щодо використання великих дзеркал для освітлення і обігрівання затіненої частини Землі вжс витримали експериментальну перевірку із використанням дзеркал з тонкої плівки, розгорнутих у космосі.

9. Цілий ряд пропозицій Ю. В. Кондратюка, об'еднаний однією ідеєю використання космічних польотів для покращення життя на Землі, знайшов своє втілення у практичній космонавтиці, а деякі 3 них знаходяться на стадії дослідницьких робіт.

Великі космісти дуже багато передбачили, у тому числі нові способи пересування у космічному просторі. Проте один із них бачив далі, i тому відкрив тасмницю, але з гуманістичних міркувань забрав іï у могилу. Так, Юрій Васильович задовго до виникнення ідеї зоряних війн, не довіряючи існуючому ладу в СРСР, утримався від публікації свої розробок і відкриттів, які могли б викликати аж ніяк не гуманний поворот у напрямку освоєння космічного простору.

Наукові та інженерні праці нашого земляка О. Г. Шаргея Ю. В. Кондратюка неповторні, як $\mathrm{i}$ його біографія. Вони не тільки самобутні, але й не повністю встановлені і недостатньо вивчені. Про це висловив свою думку один 3 вихідиів з України, який недавно пішов 3 життя, радянський вчений i ракетобудівник В. П. Глушко: «На мій погляд, ми у великому боргу перед Юрісм Кондратюком. Його внесок у космонавтику ще не знайшов достатнього відображення у пресі».

Високо оцінюеться творча спадщина О. Г. ШаргеяЮ. В. Кондратюка пресою, вченими і спеціалістами, які працюють у галузі космонавтики. Про це свідчать іх висловлювання, деякі 3 них наведені нижче.

Відомий радянський вчений В. П. Вєтчинкін у квітні 1926 р. відзначав, що Ю. В. Кондратюк не знав досягнень К. Е. Ціолковського, і писав: «Це не завадило автору отримати усі результати, досягнуті усіма дослідниками міжпланетних просторів у сукупності, що треба вважати дуже великим досягненням... Механік Ю. В. Кондратюк являє собою великий талант (на зразок Семенова Ф. О., Ціолковського К. Е. або Уфімцева О. Г.), загнаний у глухий кут, який не мав можливостей застосувати свої здібності на вищому рівні».

Працю Кондратюка можна надрукувати у тому вигляді, в якому вона зараз знаходиться... Заради збереження пріоритету за СРСР не варто відкладати друк готової праці... Такі великі таланти-самородки - надзвичайна рідкість і лишати їх без уваги 3 погляду держави було б виявом вищого марнотратства».

Газета «Вечерняя Москва» від 7 жовтня 1926 року повідомила:

НОВИЙ ПРОЕКТ МІЖПЛАНЕТНИХ МАНДРІВОК. РОБОТИ МОЛОДОГО РАДЯНСЬКОГО ВЧЕНОГО

В Головнауку надійшла праця молодого вченого т. Кондратюка «Про міжпланетні мандрівкию. Автор висловлюе в ній ряд міркувань про будову і деталі польоту ракети, призначеної для міжиланетних манлрівок. Ознайоминшись 3 працею, Головнаука визнала, що вона містить дотеші пропозищіі, які є результатом фундаментального вивчення питання автором.

Однак, на думку Головнауки, питання про виготовления такої ракети поки що може мати значения тільки при вивченні верхніх шарів земної атмосфери, ультрафіолетової радіапіі Сонця тощо.

Головнаука вирішила відустити на вилання роботи т. Кондратюка необхіцні кошти, доручивши п̄ редагування компетентному вченому.

Разом з тим Головнаука висловлюеться за надання т. Кондратюку можливості продовжувати роботу в обраній ним галузі.

Науково-популярний журнал «Наука $\mathrm{i}$ техніка» у своєму сорок першому номері за 1929 рік умістив велику статтю «До питання про міжпланетні польоти», де вказувалося, що «автору вдалося вирішити цілий ряд питань, які не вирішені іншими дослід- 
никами». Ця публікація була здійснена з участю Я. І. Перельмана i В. В. Разумова.

Німецький дослідник Роберт Ладеманн у реферативному журналі «ZFM» («Журнал польотної техніки і моторного повітроплавства», Мюнхен-Берлін, 1929 р.) відмічав: «Серед усіх тогочасних праць 3 реактивних питань, i особливо у плані польотів у космічний простір, книга Кондратюка займає особливе місце, оскільки автор висуває багато нових ідей... Уперше в Європі детально розглянуто питання співвідношення мас, а також дивовижно правильно показана дія перевантажень на організм людини».

Щоправда, у листі до К. Е. Ціолковського Ладеманн висловив думку, що Кондратюк перейняв багато чого у Констянтина Едуардовича. Але той відкинув сумніви щодо самостійності роботи молодого вченого, ще нікому не відомого.

Американський журнал «Лайф» писав 14 березня 1969 року, що інженер Джон Хуболт, який очолював групу спеціалістів НАСА по розробці і здійсненню проекту висадки людей на Місяць (проект «Аполлон»), знав про Юрія Кондратюка, «який ще 50 років тому довів, що LOR (застосування посадочно-зльотного модуля, який стартуе з селеноцентричної орбіти), буде найкращим способом досягнення Місяця...»

Академік Національної академії наук України Г. С. Писаренко (Україна) заявляв: «Складне життя у рядової людини, а у вченого-першопрохідця воно складніше стократ... Але щоб геній працював $\mathrm{i}$ жив під чужим паспортом, щоб зовсім не турбувався про славу свого імені - таке трапилося, думаю, вперше! Так, тут були свої переплетіння долі, які на цей час не насмілювалися винести на загальний огляд. I ми раді, що великому вченому, який стільки зробив для Батьківщини і людства, вдячні співвітчизники повернули справжнє ім'я. I хоча стали вже хрестоматійними назви теорія Кондратюка, винаходи Кондратюка, зрештою, кратер Кондратюка на Місяці і їх складно змінити, але все ж віднині наш видатний земляк буде мати свою неповторну біографію».

Академік Б. В. Раушенбах (Російська Федерація) пише: «Коли знайомишся 3 працями Кондратюка, - не лише 3 його книгами 3 космонавтики, але i 3 його роботами про елеватори, вітрові електростанції, загалом охоплюсш діяльність Кондратюка, то що вражає? Вражас надзвичайна оригінальність мислення. Так будівництво амбара, - нестандартне розв'язання, будівництво вежі - нестандартне вирішення, спуск на Землю - нестандартне... Політ на Місяць - нестандартне рішення. Завжди нестандартні і дуже продумані в інженерному плані рішення».
На урочистому засіданні, присвяченому 35-річчю початку космічної ери і Дню космонавтики (10.04.92р.), акілеммк В. Ф. Уткін (Російська Федерація) сказав: «емля нашої нітиизи" подарувала людству М. І. Кибальчича. Теоретичні основи космонавтики заклав видатний вчений К. Е. Ціолковський, який вплинув на формування поглядів ентузіастів ракетобудування у нашій країні. Незалежно від К. Е. Ціолковського і навіть не підозрююч. про його дослідження, розробляв проблеми космонавтики механіксамоук Ю. В. Кондратюк. Багато із запропонованних ним рішень втілилося у життя. За схемою Ю. В. Кондратюка здійснювалися польоти американських астронавтів на Місяць. Його ідеї про спускний апарат з теплозахисним екраном і зміни екіпажів космічних станцій теж стали реальністю».

Льотчик-космонавт В. І. Севастьянов (Російська Федерація) у передмові до книги А. В. Даценка \&Я полечу туда... писав: «Ю. В. Кондратюк, як і К. Е. Ціолковський, був попередником таких корифеїв практичної космонавтики, як С. П. Корольов, Ф. А. Цандер, М. К. Тихомиров, Ю. О. Победоносцев. За життя Шаргею-Кондратюку не довелося побачити втіленими свої проекти i, це його особиста трагедія. Але досягнення практичної космонавтики, Останкінська телевежа (створена учнем Кондратюка), екологічно чисті вітроелектростанції (нехай невеликої потужності), які випробовувалися на полігоні Киівського політехнічного інституту «Десна» і зараз працюють на станції Новолазарєвська у Антарктиді, - тріумф його генія, найкращий йому пам'ятник».

Академік Національної академії наук України Я. С. Яџків (Україна, 1996 р.) писав: «У 1997 році відзначається 100-річчя від дня народження видатного українського вченого, одного 3 піонерів космонавтики і автора багатьох винаходів Ю. В. Кондратюка. Це ім'я тривалий час не було відоме в Україні через різні обставини особистого життя Ю. В. Кондратюка. Але його праці були широко відомі спеціалістам у світі, його ім'я згадували при здійсненні епохального польоту людини на Місяць, його наукові здобутки до цього дня не втратили своєї цінності».

Письменник-історик, лауреат Державної премії ім. Т. Г. Шевченка В. О. Шевчук (Україна, 1996 р.) казав: «Ім'я Ю. Кондратюка належить Україні. Він один з світових геніїв космонавтики, за його «земною» філософією робиться майже все у цій галузі. $\mathrm{y}$ цьому він перевершив К. Е. Ціолковського та інших космістів Землі. За його схемою відбувся політ астронавтів США до Місяця».

Віце-президент Національної академії наук України, академік В. Г. Бар'яхтар (Україна, 1997 р.) відмічав: «Передовий косміст, блискучий інженер 3 нестандартними, але продуманими рішен- 
нями, піонер космічної діяльності Ю. В. Кондратюк - скарб світової науки, національне надбання українського народу».

Цю низку висловлювань, на наш погляд, варто завершити словами одного з дослідників творчості і біографії Ю. В. Кондратюка Б. І. Романенка (Російська Федерація): «На цей час усе слідує не тільки філософським визначенням Юрія Кондратюка, але і науково-технічним засобам реалізації його цілей».

У справу практичної космонавтики вклали свій талант і працю багато вчених та конструкторів космічної техніки - вихідців 3 України.

Так, з 22 генеральних (головних) конструкторів, які очолювали 10 основних конструкторських бюро СРСР і країн СНД протягом 40 років космічної ери, 11 спеціалістів мають відношення до України (хто народився, хто навчався, хто працював...), а саме: В. П. Глушко, В. М. Ковтуненко, С. М. Конюхов, С. П. Корольов, С. С. Крюков, А. К. Недайвода, М. Ф. Решетнев, Ю. П. Семенов, В. Ф. Уткін, В. М. Челомей, М. К. Янгель.

Але не тільки генеральні (головні) конструктори втілювали космічні ідеї Ю. В. Кондратюка (О. Г. Шаргея) і К. Е. Ціолковського, а і багато колективів виробничих і наукових організацій усіх республік колишнього Союзу, космодромів Байконур, Плесецьк, Кап'яр та ін. Усі ці колективи були першопрохідцями науково-технічної революції, невідомими підкорювачами космосу і славними послідовниками на практиці ідей Ю. В. Кондратюка (О. Г. Шаргея).

Серед них сотні тисяч працівників України, які, штурмуючи космос, завжди залишалися на Землі: Абраїмов В. В., Агарков А. В., Айзенберг Я. Є., Алекссєв Ю. С., Андрющенко А. Г., Асмолов О. О., Бакланов О. Д., Балашов Л. Л., Баранов Г. Л., Березовський В. А., Бєланов А. В., Белізін М. В., Бондаренко С. І., Борушко Ю. М., Брунц А. В., Будник В. С., Бушусв Є. І., Василенко Б. Є., Васильєв В. П., Венедиктов Ю. І., Верещак О. П., Веркін Б. І. Виноградов В. А., Войтенко О. М., Герасимчук А. А., Гладілін В. С., Гомозов В. I. Гончар А. С., Горбулін В. П., Грачов В. В., Губанов Б. І., Гудименко А. І., Готинян В. С., Дедснок В. П., Дорошкевич В. К., Дормидонтов А. Г., Драновський В. Й., Дудник О. В., Дурасов В. Т., Жарковський В. С., Задонцев В. А., Завалішин А. П., Залюбовский І. І., Замірець М. В., Златкін Ю. М., Зуєв В. В., Івченко В. М., Кавелін С. С., Калмиков А. І., Катасв В. І., Козачище Л. О., Колногуз А. В., Комаров В. Г., Комісарчук А. А., Комонов В. Г., Копил О. А., Кордюм Є. Л., Корепанов В. Є., Коротаєв Г. К.,
Корума С. С., Коснирсв В. К., Костик Р. І., Коцаренко М. Я. Кошевая С. В., Кузнсцов Е. І., Кунцевич В. М., Купчиков К. Ф., Кучма Л. Д., Лапчинський В. Ф., Лебедєв О. Д., Лебедсв О. М., Литвиненко Л. М., Литвинов В. А., Ломан В. І., Лялько В. І., Лящев Г. І., Макаренко Б. І., Макаров О. О., Макаров О. М., Малков А. Б., Мацевитий Ю. М., Моцний Ф. В., Мащенко О. М., Морщаков Є. О., Назаренко С. А., Недобсжкін В. О., Негода О. О., Новіков О. В., Осіпов М. В., Павловський М. А., Паппо-Користін В. Н., Патон Б. Є., Передерій А. І., Пилипенко В. В., Платонов В. П., Поляков Є. П., Попєль А. М., Пяних В. В., Раубішко С. С., Романенко В. М., Романов Л. П., Руденко В. Ф., Рябцев С. Г., Салтиков Ю. Д., Свищ В. М., Сербін В. М., Сергеєв В. Г., Синельников Є. Я., Свіріденко О. Г., Сметанін Ю. О., Сімагін В. Г., Сорокін А. О., Стегній А. І., Стешенко М. В., Страшко В. Я., Талмазан В. І., Топчій Д. Г., Торчинська Т. В., Травченко В. І., Трефілов В. І., Уралов В. О., Ус С. І., Фролов І. Ф., Хачатурян Г. А., Шифрин Я. С., Шмаров В. М., Шнякін Н. С., Шокало В. М., Щербина $Є$. С., Щетина О. І., Цибка П. І., Цимбал В. М., Ямпольський Ю. М., Яровий К. Н., Яцків Я. С. і багато інших.

I нам, безперечно, шкода, що видатний радянський вчений O. I. Чижевський, введений в оману окремими особами, виступив 3 протестом у 1962 році проти Ю. В. Кондратюка, який, за його словами, не мав ніякого відношення до космонавтики.

За рішенням 28-ї сесії Генеральної конференції ЮНЕСКО 21 червня 1997 р. увесь світ відзначає пам'ятну дату - 100-річчя 3 дня народження українського вченого і дослідника, піонера космічної техніки Юрія Кондратюка (О. Шаргея). 


\section{3. ЛИСТИ І ВИТЯГИ З МАТЕРІАЛІВ ТА ПЕРШОӤ ПРАЦІ}

\section{1. Полтавсько-Петроградський рукопис. о. Г. Шаргей}

- асамперед привертає увагу жорстка самокритичність автора. Шілі сторінки перекреслені. Рукопис, по суті перша наукова праця, серйозна праця, юочевидь не призначався для друку. Автор не завжди послідовний, постійно повертаеться до раніше розглянугих питань."

\section{Перший зошит}

Загальна теорія.

1-ша умова польоту - бути не смертельним для людини, як при польоті туди, так $\mathrm{i}$ назад. 2-га - керованим. 3 цих умов виходить вибір типу літального апарата.

$I$ умова. Цей апарат повинен не допустити значних перевантажень і потребуе відсутності механічних прискорень понад ту межу, яку може витримати людина $(5-10 g)^{* *}-$ тобто потребує надання швидкості протягом порівняно великого проміжку часу на великій відстані.

Оскільки для надання механічного прискорення необхідна точка опори..., то очевидно, доводиться возити точку опори з собою - діяти віддачею - реактивний прилад (c. 1).

II умова потребує також точки опори, яку возять з собою реактивного приладу.

Чи можливе вдосконалення польоту на реактивному приладі при існуючих нині відомих речовинах? Теоретично можливе, у всякому разі, від сили речовини залежить лише величина приладу потрібна для... (польоту) 3 даною кількістю інертної речовини (людина, камера, прилади)... (с. 2).

(Відмітимо, юнак не знав ні про праці К. Е. Ціолковського, ні, тим білыше, про праці зарубіжних вчених. Але приходить до правильного висновху: вириладэ повинен бути реактивним).

Тут і далі петитом замітки, зроблені А. В. Даценком при знайомстві з Полтавсько-Петроградським рукописом.

** Терміни жмеханічне прискоренняь, єперевантаженнян, введені О. Г. Шаргеєм (Ю. В. Кондратюком), збережені у наступному тексті.
Дивись початок 3-го зошита; тут неправильно. (с. 3).

(I далі 3-9 c. перекреслеиі хвилястою лінією зверху вииз, від 9-і залишена верхня половина, усі ці сторінки містять математичні міркування і розрахунки). Загальна форма приладу поки не уточнена. У всякому разі, у ній будуть камера для людини з приладами і провізією; резервуар для активної речовини (палива) і (всередині його) дуже довга труба 3 отвором назад, по якій будуть розширятися і виштовхувати себе гази (с. 10).

(Таким чином, 18-річний юнах запропонував для польоту у хосмос ракету на хімічному паливі (жактивна речовита»), яка містить розріджені гази (кисень $\mathrm{i}$ нодень). Ніхто іниий у світі не робив у такому ранньому віці такопо фундаментального відкриття у галузі міжпланетних польотів. Термохімічну ракету до О. Г. Шаргея запропонуван лише К. Е. Ціолковський (рідинна) і американець P. X. Годдард (твердопалимиа)).

Низ с. 11 і 12 також обрізаний. На цих сторінках медико-біологічні думки, про живучість людського організму.

Подолання земного тяжіння (с. 13).

(Знову математика, розрахунки швидкості, при якій літальний апарат зможе подолати земне тяжіння, виводяться формули співвідношення стартової маси снаряда до маси жнеактивиої частини» - корисного навантаження, кінцевої маси снаряда.)

(c. 14 i 15 ).

У результаті отримуємо формулу співвідношення снаряда до неактивної частини

$$
4^{1100 \sqrt{1} / P} \times 4^{\frac{1100 \sqrt{2} / P}{(n-1)}} \times 4^{1100 \sqrt{1} 7 P\left(1+\frac{1}{n-1}\right)^{n}}
$$

(c. 16 i 17)

(Це виведена Олександром Шаргеем основна формула ракети.)

Теорія зупинки. Зупинка нічим не відрізняеться від польоту і повернення на Землю, окрім кількості і потенціалу.

(Юний вчений геніально просто вирішуе завдання, яке не було вирішене до нього жодним вітчизняним теоретиком міжпланетних подорожей. Йдеться про висадку людини на небесне тіло, яке має значне поле тжжіння. Олександр Шаргей розуміе, що лля посадки усього літального апарата на це тіло, а потім ляя злету $з$ нього буде потрібна велика кількість палива. Чи можна зменшити цо кількість? Олександр приходить до висновку - так.

француза Віктора Куассака, чкі побачили світ у 1915 i 1916 рр. В них описана схема висадки на іншу планету, яка схожа на схему О. Шаргея, інші розробки, аналогічні пропозиціям вченого. 
«Шоб не внтрачати великої кількості активної речовини, можна не зупиняти усього снаряяа, а лише настільки зменшити його швидкість, щоб він рівномірно рухався по колу якомога ближче до тіла на якому зроблена зупинка, після цього виділити 3 нього неактинну частину с такою кількісто активноі речовини, яка необхіпна дия зупинки неактинної пастини і для того, щоб потім вона змогла наздогнати (приеднатися знову) до іншої частини снаряла.

«Як бачимо, полтавський гімназист ще у 1914 рощі пропонував ту схему польоту, за якою перез десятиліття відправляться 3 Землі апарати иа Місящы, Марс. Венеру, за якоьо американські астронавти здійснять політ з висадкою на Місяці.

Схема пключае політ до Місяия або планети, незначне гальмувания переходу літального апарата на орбіту шатучного супутника, відокремлення від основного апарата посадочного модуля невеликої маси, його посалка, робота на поверхні небесного тіла, зліт у призначений пас і стикування 3 хораблем-маткою, запуск двигунів основного корабля і повернення на Землю. Просто і геніально! Џю схему називають етрасою Кондратоказ).

Ускладнення, які вносить атмосфера... для подолання значної ît щільності. Це негативне явище буде як на шляху туди, так і при поверненні (с. 19).

«... Потрібно злетіти верст на 50, шоб шкідливого впливу уникнути майже зовсім... До цісї висоти потрібно добратися, діючи складом, який працюе однаково добре і при атмосферному тиску - підриваючи піроксени або іншу речовину...» (с. 20).

(Шойно освосні розділи науки Олександр Шаргей застосовунап для справи Цікаво те, що знаючи методи вирішення дифферснційних (у всякому разі простих) ріянянь, він виводить основну ракетиу формулу, користуючись теорією границь, тоді як К. Е. Ціолковський шю пазвану його іменем формулу вивів (i опублікуnап у 1903 році) за допомогою нескладиого диференційного рівияняя. За таким же принципом у 1913 році виводить ракепну формулу француз ЕноПельтрі і американещь Роберт Годнард. Відмітимо: усі незалежно один ві, одного.

Чому ж Олексанар Шаргсй виводить щю формулу не тахим шляхом? Спрана в тім, що юний вчений намагався уявити політ ракети, безперестанний приріс швитості снаряда фізино, як резульат спалення одша за одною поршій палива, що у математичному вигляді $\in$ геометричною прогресіею - при згоранні палива, пага порцій зменшуеться. Ясно відчуваючи процес дій ракети, намагаючись передати це почуття тим, хто буде колись знайомитися з його роботою, він виводить основну формулу ракети за допомогою граничного переходу. Тут, ак іу наступних своіх роботах, Олексантр Шаргей намағасться наочнопоказати фізичний зміст, механізм сноіх роздумів, часто опускаючи докази і роз'яснення, які, на його думку, для грамотного фізика, механіка, очевидні.

Двадиять сторінок першого зошита увібрали у себе лише частину думок пре шляхи освосння міжпианетного простору. Озброений новими знаннями, захоплений пошуком рішень усе нових питань, які виникають по мірі заглиблення у дивовижно захоплюючу роботу, Олександр Шаргей продовжує записи свої думок, пропозищій, висновків)

\section{Другий зошит}

Повернення на Землю: Неактивна частина снаряда повинна бути планером... два способи аеродинамічного спуску... (с. 21).

...Великою перевагою цих способів с те, що вони дають велику економію активної речовини... автоматичний спуск.

Наводяться формули повернення обома способами (с. 22).

(Неактивна частина снаряда повинна буги планером. Це, вказуе автор, дае велику економію палива. Він пише про автоматизацію спуску, наводить формули ваеродинамічного спускуз.)

Якщо буде великий рух із Землі у міжзоряний простір, то вигідніше зробити гармату (електричну, яка надавала б снаряду значну початкову швидкість; це дало 6 змогу 3 меншою кількістю активної речовини та меншою витратою енергї̈ швидше здійснювати далекі польоти... Јінійні ел. двигуни? Меркулов? Снаряд... може (в атмосфері) розколюватися, як метеор (с. 23).

Про польоти у Сонячній системі (розраховусться 3-тя космічна швидкість) (с. 24)

\section{Порядок польотів:}

I - випробувати дію пристосувань для підйому в атмосфері;

II - політ не особливо далеко від земної поверхні,

на декілька тисяч верст;

III - політ на Місяць без зупинок там (особливо політ навколо

Місяця);

IV - політ на Місяць із зупинкою (с. 25).

(Юнах сміливо намічае стратегію оволодіння міжпланетним простором, його початковий етап).

Важливе зауваження: скрізь, де я говорю про активність речовини iï потрібно розраховувати на вагу цісї речовини + вагу того посуду, у якому вона знаходиться; коли ми використасмо деяку частину активної речовини, ми залишимо і той посуд, у якому вона була. Тому краще, а можливо і необхідно, тримати увесь запас активно речовини не в одному посуді, а в декількох, які прогресивно зменшуються. Це тим прийнятніше, що один посуд зовсім не зручним. (с. 36 і 37 ).

(Усередині лругого зошита мизнаходимо піонерську для вітчизняної науки ідею про жбагатокомплектнув (багатоступеневу) ракету

Як бачимо, Олексанар Шаргей висунув, а трохи пізніше і обгрунтував ідею батаступеневої ракети, поступившись лише американщю Р. X. Годдарду, який про багатоступеневі ракети говорив у 1913 році. К. Е. Ціолковський цим питаниям зайнявся у другій половині $1920-x$ років). 
Керування і стійкість. Газовий резервуар... жироскоп (с. 38).

Цих двох пристроїв достатньо для керування снарядом, оскільки напрям прискорення завжди паралельний його осі. Щоб надати снаряду той або інший оберт новколо його осі, потрібно лише пробігтися всередині його (або навіть тільки обертатися,..чи просто махати рукөю) у зворотній бік, так що усякі прилади зайві (c. 39 ).

Двовісний астатичний жироскоп. (Нижче усе перекреслено словом «нісенітниця») (с. 40).

Двовісний жироскоп... (с. 41 ).

База для польотів. Базу найкраще влаштувати на якому-небудь тілі, можливо, меншому (Місяці, супутнику Марса), на якому був би матеріал для активної речовини, для отримання якої потрібно там встановити машини (сонячні). Така база корисна своім малим потенціалом сили тяжіння. На ній треба мати запаси активної речовини і усі прилади. На неї ж можна прилітати на легшому пасажирському снаряді. Зробивши запаси речовини на цій базі, можна здійснювати солідніші польоти, оскільки значно менше активної речовини знадобиться для подолання потенціалу (тяжіння) самої бази (с. 44)

(У своїй першій роботі Олександр Шаргей пропонуе розмінувати міжпланетн проміжні бази на небесних тілах, розраховуючи використовувати для забезпечення міжпланетних перельотів знайдені там і перероблені корисні копалини Пізніше пін зрозуміе, що стпорювати такі бази спочатку буде занадто важко, певно, иеможлино. До того ж вони будуть знаходитись на значній відаллі ві, Землі. Тому, розвиваючи спою ідею, він ставить питання про бази - штучні супутники Місяця і Землі, що було пізніше здійснено).

\section{Третій зошит}

У початковому виведенні формули збрехав... Вирішив усе переосмислити (с. 49)

Теоретична формула ваги ракети:

$$
M=m \mathrm{e}^{v / \sqrt{2} \bar{p}} \text {. }
$$

...Підлітаючи до Землі по дотичній, зовсім не користусмося активною речовиною, а користуємося атмосферою... (с. 49-51).

Ось формула для польоту 3 Землі і назад, зважаючи на витривалість людини:

$$
M=m \mathrm{e}^{2 \sqrt{ }] / P\left(1+\frac{1}{k-1}\right)} .
$$

(c. 60 ).
55 разів. Ура! Цілком виконуемо (с. 61).

(Зробивши нескладні розрахунки, молодий вчений переконався, що якщо застосувати у ракетному двигуні паливо, яке отримаємо при з'еднанні кисню волнем, гримучий газ, або інше термохімічне паливо, то можна буде досягиути швидкості жусього лише одиниці, у кращому випадку - десятки верст за секунду. Отже, можна планувати польоти лише у межах Сонячної системи. Про польоти до зірок, на фшші планетні системи залишається тільки мріяти.

Тільки швидкості порядку швидкості світла дозволять здійснити контакти з іншими зорьними світами).

(Закреслено. $€$ напис: «Запитати у рідних про випромінювання радію і про випромінювання взагалі у закатодних променях» (с. 62 i 63)).

Про інші можливі реактивні прилади:

I - механічний, котушка 3 дротом (c. 64).

II - використання «швидкого» випромінювання $(\alpha, \beta)$ радію.

Оскільки це випромінювання матеріальне, то, імовірно, воно повинно давати і відповідну механічну реакцію-віддачу, якою можна скористатися, доводячи це випромінювання до необхідно інтенсивності. Енергію ж для випромінювання можна брати 3 сонячного світла... (с. 65).

(Так Олександр Шаргей розпочав розробку питащь використання сонячної енергії для потреб космічних апаратів).

Використання сонячної енергії (с. 66).

Дзеркала 3 приймачами тепла. Параболічне дзеркало направляється віссю на Сонце. Сонячні промені, відбиваючись, збираються у фокусі і проходять там крізь отвір у обігрівачі (с. 68 i 69).

Параболічні дзеркала можуть бути різних видів. Форми параболоїда обертання, або форми поверхні прямого циліндра, в якого в основі сегмент параболи (с. 68a, 68б).

Обігрівальні трубки (Н, О) (с. 68в).

Конструкція дзеркала для концентрації сонячної енергії (c. 70 ).

Сили сонячного освітлення. Якщо вдасться побудувати реактивний снаряд, який працює віддачею катодних променів, то лише від Сонця зможемо брати достатню кількість енергії і переробляти iï 3 теплової в електричну (с. 72)

Отримання реакцій від матеріального випромінювання елементарних частинок (с. 77). 


\section{Четвертий зошит}

Про посудини (баки) для компонентів палива (с. 83). Обігрівачі компонентів палива перед подачею у реактивний двигун (с. 93).

Змішування струменів для отримання однорідної суміші у камері згоряння (с. 95).

Температура руху середовищ... якщо в атмосфері рухається полірована поверхня під кутом до напрямку, то чим менший кут атаки, тим менше буде нагріватися при русі ця поверхня (с. 97).

3 наведеного видно: щоб зробити можливим спуск за допомогою утримуючої дії атмосфери, необхідно поверхні снаряду, повернені вперед, зробити майже паралельними руху в повітрі, інакше снаряд згорить швидко, але яскраво (с. 101).

(Олександр Шаргей рекомендуе ракету - жснарждр робити обтічної форми. Зауважимо, що у наступних роботах він висупає ідею спускного аптарата антиаеродинамічної форми 3 застосуванням автоматично керованої термозахисної поверхні. Це потрібно для того, щоб швидше і безпечніше гасити величезну швидкість апарата, яхий повертасться на Землю, за рахунок його великого овору).

(С. 102-103 чисті).

Майже усе тут, у 4 зошитах написане, - придумане мною під час перебування у юнкерському училищі приблизно від перевороту і до 25 березня (с. 104).

(Доводиться дивунатися, чому він фактично ввів в оману читача, датуючи спою роботу, яка наловнена піонерськими ідеями, 1917 роком і написав, що на де витратив пілий місяць (щоправда ємайжељ). Тут, як пізніше, 3 'ясувалась його повна неповага до питань пріоритету. Через двадцять один рік, коли передавав документи, віи уже позначив той же рукопис 1916 роком, добре не подумавши.

Непоказиий 3 вигляду зошит з полтавсько-петроградсъким рукописом містить відкриття і цікаві пропозицій, які висунув молодий вчений, нічого не знаючи про праці К. В. Ціолковського, Р. Х. Годдарда, інших сучасників. Ідеі Олександра Шаргея, викладені у його першому рукописі, згодом були підтверджені практичною космонавтикою. I тому незрозуміло, чому цю роботу часто зовсім не враховують оцінюючи творчу спадшину вченого, тоді як вона є фундаментальною щодо усіх наступних праць Шаргея-Кондрапока. Першою його науковою працею називають київський рукопис 1918-1919 років «Тим, хто буде читати, щоб будуватиз. Чому?

Потрібно відзначити також, що юний автор (адже йому було лише 17 років) 3 самого початку вддув євеличезність $\mathrm{i}$ невизначеність можливих наслідків від виходу людини у міжпланетний простір і тому тримав свою роботу у секреті. У цьому проявився високий гуманізм молодого дослідника. Наївно думав, як сам він згодом писав, що достатньо опублікувати його пращо, ч्रк терміново хто-не- будь, маючи достатні матеріальні кошти, здійснить міжпланетиий переліт. Ав тор мав сумнів, чи не буде використаний дей політ у війсъкових цілях. I вің вирішив тримати слій рукопис у таемниці...).

\section{2. Витяги 3 першої передмови Ю. В. Кондратюка} до книги «Завоювання космічного простору»

я праця в основному була написана у 1916 році після чого вона тричі доповнювалась і перероблялась. Автор сподівався, що йому вдалося подати завдання завоювання Сонячної системи не у вигляді теоретичних основ, розвиток i практичне застосування яких належать науці i техніц майбутнього, а у вигляді проекту, хоч і не деталізованого, але вже 3 конкретними цифрами, здійснення якого імовірно і у теперішній час для нашої сучасної техніки, після серії експериментів, які нс являють собою проблеми. Здійснення це до того ж, починаючи від попередніх експериментів i закінчуючи польотами на Місяць, вимагало меншої кількості матеріальних ресурсів, ніж спорудження декількох великих військових кораблів.

Про існування на цю ж тему праці інженера Ціолковського автор дізнався лише згодом, і лише мав можливість ознайомитися з частиною статті «Дослідження світового простору реактивними приладами», надрукованої у журналі «Вісник повітроплавства» за 1911 р., причому переконався у пріоритеті інж. Ціолковського у вирішенні багатьох основних питань. 3 наведеної статті, однак, не були викинуті параграфи, які не містили нічого нового, 3 одного боку, щоб не порушувати цільності викладу і не відсилати зацікавлених до рідких тепер і важко розшукуваних номерів «Вісника повітроплавства», 3 іншого ж боку тому, що іноді ті ж самі теоретичні положення і формули, висвітлені під іншим кутом, дають нове розуміння усьому питанню. При усьому тому автор так i не отримав можливості ознайомитись не лише з зарубіжною літературою 3 даного питання, але навіть з другою частиною статті інженера Ціолковського, надрукованої у журналі за 1912 рік.

Багато 3 наведених у цій роботі формул і майже усі цифри подані зі спрощеннями і округленнями, часто навіть доволі грубими; причина цьому та, що необхідний для детальної роботи дослідний матеріал ще відсутній у теперішній час, внаслідок чого для нас немас рації копатися у сотих частках, поки ми не можемо бути переконаними і за точність десятих; ціллю деяких викладок цієї праці було лише дати уяву про порядок фізичних величин, з якими нам доведеться мати справу, i про загальний характер їх 
зміни, оскільки розрахувати іхні точні значення до відповідних експеримснтальних досліджень неможливо. 3 аналогічної причини у роботі відсутні і конструктивні рисунки: загальні принципи конструкцій легко висловити і на словах, деталі нами поки що не розроблено; тому усяке креслення, яке містить у собі деякі нсобхідні окремі форми, замість посібника, було б швидше вадою до наукового розуміння.

Червень 1925 p.

Ю. Кондратюк

\section{3. Витяги 3 другої передмови автора до книги «Завоювання міжпланетних просторів»}

оркнусь основного загального питання цієї роботи, зовсім не висвітленого у початковому викладі - питання про очікувані результати для людства від виходу його у міжпланетний простір.

Піонер досліджень даного предмсту проф. Ціолковський бачить значення його у тому, що людство зможе заселити своіми колоніями великі простори Сонячної системи, а коли Сонце охолоне, відправитися на ракетах для поселення у світи, які ще не охолонули.

Подібні можливості, безперечно, не виключені, але усе це пропозиції віддаленого майбутнього, занадто віддаленого.

Без сумніву, ще довгий час вкладення коштів у покрашення життсвих умов на нашій планеті буде рентабельнішим, ніж заснування колоній поза ї межами; не треба забувати, що порівняно із загальною площсю поверхні нашої планети лише незначна іiі частина заселена і експлуатусться належним чином.

Подивимось на проблему виходу людини у міжпланетний простір з більші «сьогоднішнього погляду: чого ми можемо конкретно очікувати у найближчий час - максимум - десятиріччя, рахуючи від першого польоту з Землі.

Якщо не вдаватися у необгрунтовані фантазіі, то наші сподівання будуть наступними:

1. Безперечно велике збағачення наших наукових знань 3 відповідним відображенням цього і у техніці.

2. Можливе, більш або менш імовірне, але не достовірне, збагачення нашої техніки цінними речовинами, які можуть бути знайдені на інших тілах Сонячної системи i які відсутні, або занадто рідко зустрічаються на нашій планеті.

3. Можливі інші дари Сонячної системи, які ми зараз і не передбачаємо, і які можуть бути або і не бути, як, наприклад, результати спілкування 3 імовірним органічним світом Марса.

4. Безперечна можливість для людства оволодіти ресурсами, за допомогою яких можна буде докорінно покращити умови існування на земній поверхні, - проводити іi меліорацію у грандіозних розмірах, здійснювати у недалекому майбутньому заходи і такого порядку, як, наприклад, зміна клімату цілих континентів.

Йдсться не про що іншс, як про утилізацію невичерпних запасів енергії сонячного світла, яка настільки ускладнена в умовах земної поверхні, що стає менш рентабельною, ніж експлу атація палива, води і вітру, і яка, навпаки, буде незрівнянно рентабельнішою у просторах, де відсутні атмосфера і вага. Тому по можливості у найближчий час потрібно розпочати по-справжньому господарювати на нашій планеті і треба бачити основне величезнс значення для нас у завоюванні простору Сонячної системи.

Згадуючи дивовижні можливості науки i техніки останніх років, мимоволі постас запитання, чому не вирішено на практиці до цього часу завдання міжпланетних сполучень, у порівнянні іншими досягненнями, не таке вже й складне, якщо підходити до нього науково, а не 3 витріщеними від здивування і жаху очима, аж ніяк не грандіозне у розумінні технічних засобів, але яке має, в той же час, неоціненне значення.

Запитуючи себе, доходиш висновку: від нестачі ініщіативи відваги, з одного боку, і нерозуміння практичного значення цього завдання, 3 іншого. Яккби мета цього завдання при тій же складності була ясніше виражена у доларах, і не вражала б свосю екстраординарністю, американці, імовірно, вже володіли б ним, а не вели 6 , як і німці, лише попередні досліди, спрямовані, до того ж, по не зовсім правильному шляху.

У 1921 році я прийшов до несподіваного розв'язання питання про обладнання постійної лінії сполучсння із Землі у простір назад, для здійснення якої застосування такої ракети, яке розгля далося у цій книзі, необхідне лише один раз; у 1926 році - до аналогічного вирішення питання про розвиток ракетою початкових $1500-2000 \mathrm{~m} / \mathrm{c}$ ї̈ швидкості відльоту без розходу заряду і в той же час без застосування грандіозної артилерійської гармати-тунелю, або надпотужних двигунів, або взагалі якихось великих споруд. Вказані розділи не увійшли у цю книгу; вони занадто близькі до робочого проекту оволодіння світовим простором - занадто близькі для того, щоб іх можна було опублікувати, не знаючи, хто і як цими даними скористається.

Жовтень 1928 р.

Ю. Кондратюк 
3.4. Напис на титульному аркуші книги «Завоювання міжпланетних просторів», надісланої К. Е. Ціолковскому (І квартал 1929 р):

3 повагою піонеру дослідження міжпланетних споЗлучень від автора.

Юр. Кондратюк.

\section{5. Лист до наукового редактора В. П. Ветчинкіна (I квартал 1929 р)}

U ановний Володимире Петровичу!

Радий мати, нарешті, можливість піднести Вам на пам'ять свою книжку. Видав іï з великими муками бісівськи дорого - місцеві набирачі ніяк не могли справитись 3 формулами, а я був майже безперервно у роз'їздах. Продовжую працювати по елеваторній справі - переважно проектування і виконання емеханізованих амбарів» - (елеватори з круглого лісу i з великими силосами). Збираюсь на днях побувати у Москві у зв'язку 3 одним 3 мої винаходів - елеваторним ковшем, навколо якого зараз піднявся деякий шум, - не знаю, чи вдасться насправді з'іздити.

Усього найкращого. Мoc шанування

Юр. Кондратюк.

\section{6. Лист до професора М. О. Риніна}

Џ Манвний Миколо Олексійовичу!

Відчуваючи, шо суто особистий бік мого життя не становить інтересу, спробую повідомити переважно те, що має відношення до моїх досліджень з теорії міжпланетного сполучення.

Початково наштовхнуло мою думку на роботу у бік оволодіння світовим простором, або, взагалі у бік грандіозних і незвичних просктів - рідкісне за силою враження від прочитаної мною у юнацтві талановитої індустріальної поеми Келлермана еТунель».

До цього часу мій науковий $\mathrm{i}$ технічний багаж становив: незакінчену середню освіту плюс дещо несистематизовані доповнення, зроблені самостійно, стосовно вищої математики, фізики загальних теоретичних основ техніки 3 нахилом більше до винахідництва і самостійних досліджень, аніж до детального вивчення вже знайденого і відкритого.

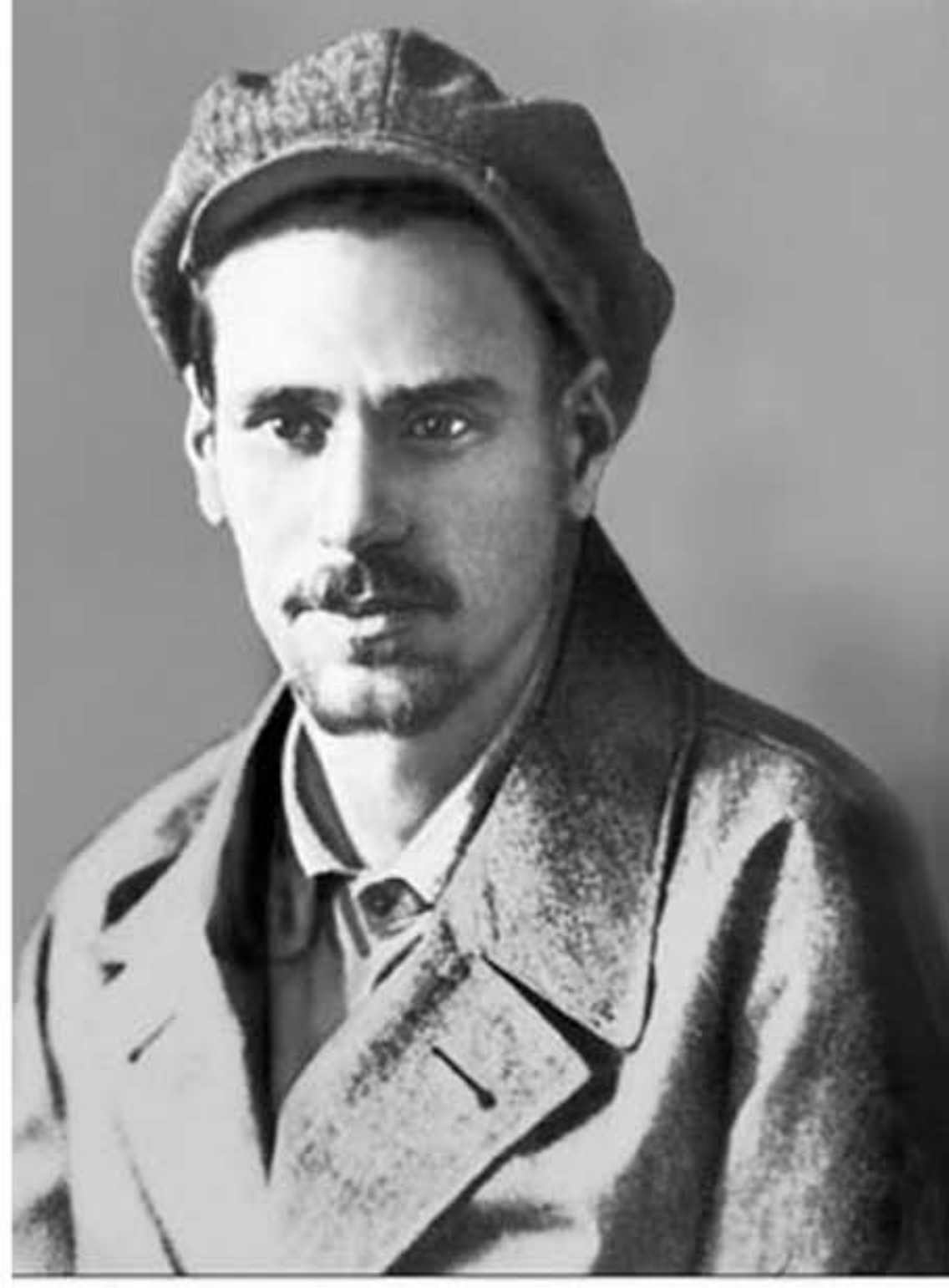

Юpia Boconemes Kontponos (1927 p.) 


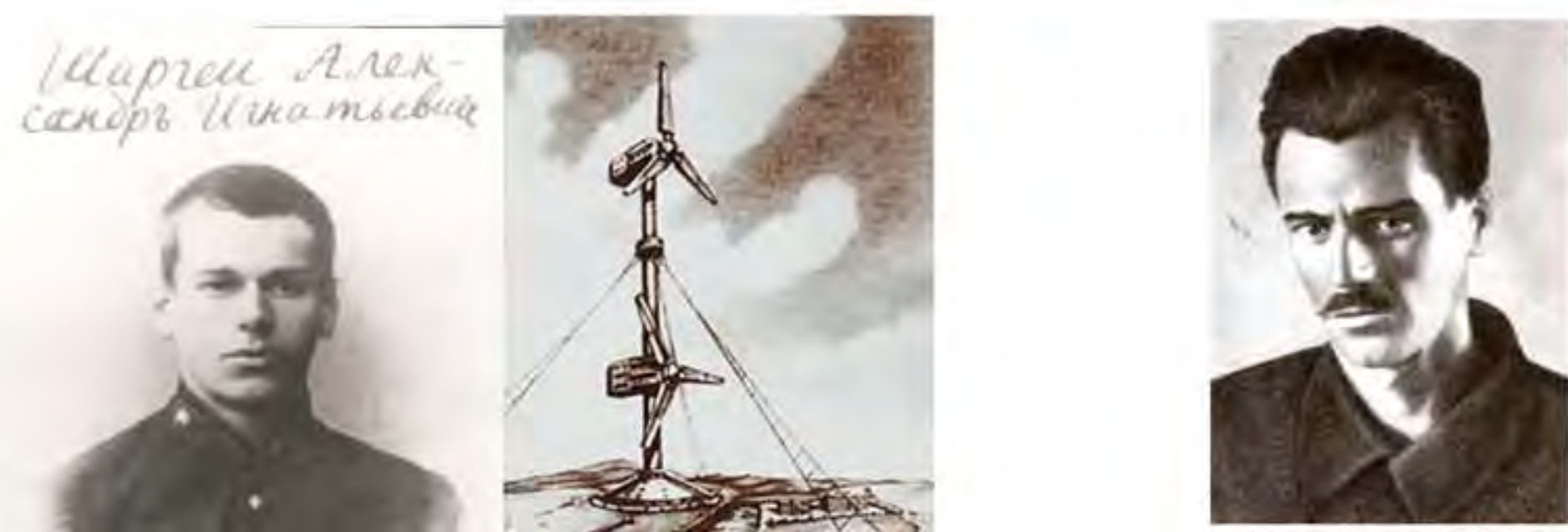

ю. B. Koncepartak

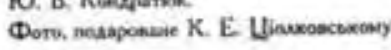

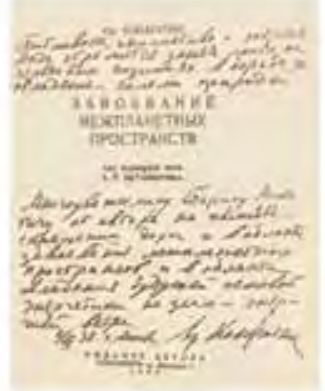

Tirryeses ctopioss nenen - 3abameasear

tixncemennax npostogia"
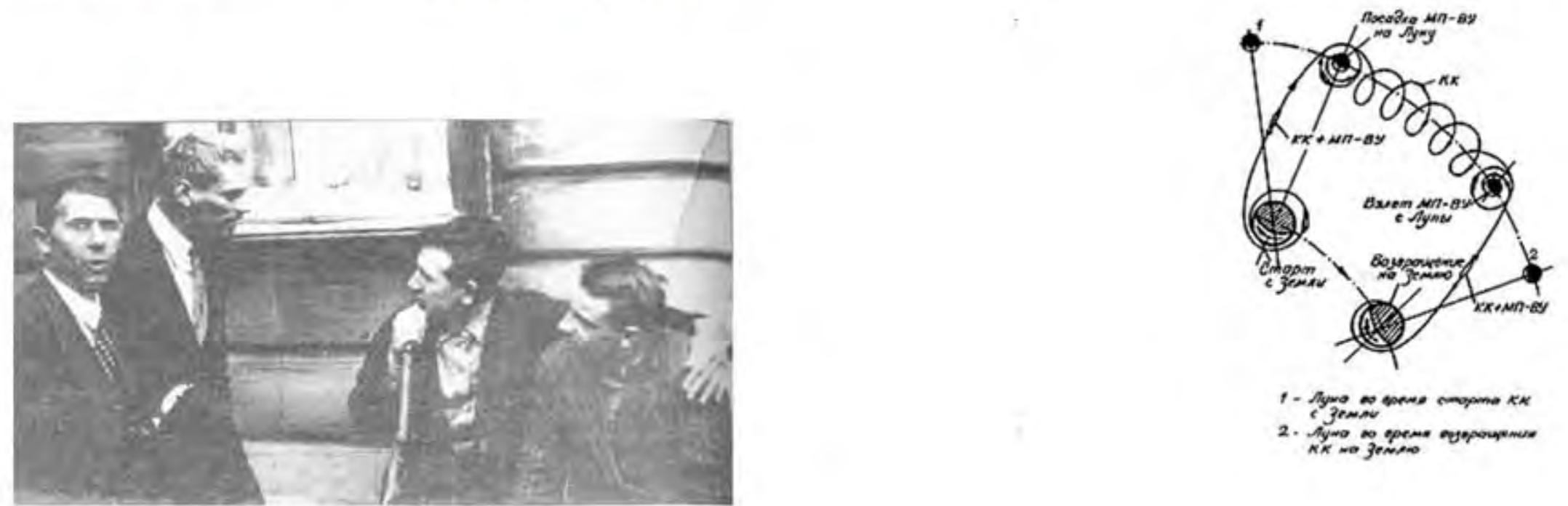

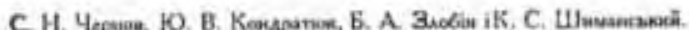

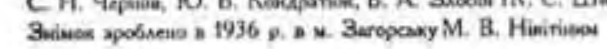


Мною були евинайденіз: водяна турбіна типу колеса Пельтона, замість млинових водяних коліс, які я вважав сдиними двигунами: гусеничний автомобіль сля ізди по м'яких і сипучих грунтах; безпружинні відцентрові ресори; автомобіль для ізди по нерівнія місцевості; вакуум-насос особливої конструкції; барометр; годннник 3 довгочасним заводом, електрична машина змінного струму високої потужності; парортутна турбіна $і$ багато інших речсй. частково технічно абсолотно непрактичних, іноді аже відомих, іноді нових, заслуговуючих подальшоі розробки і втілення.

В математиц - сталі дослізжения геометричної аксіоматики (переважно постулату змінних), евідкриттяо основних формул теорії кінцевих різниц відмінностей $i$ аналізу та багато менш вагомих речей, які с відкриттям раніше відомого. В хіміі і техніці - основні елементарні уявлення. У фізиці - стійке прагнення спростувати аругий принщи термодинаміки (характерно, що це, здасться, спільна риса з К. Е. Ціолковським) - навіть у філософії намаганви побудови логічних систем, шо закінчилось разом 399 відсотками самого інтересу до філософіі жвідкриттямо важкосприйнятного приниипу детсрмінізму.

Враження від Келлерманінського «Тунелю було таке, що негайно услід за його прочитаняям взявся опрацьовувати, наскільки дозволяли мої сили, майже одночасно дві теми: пробинка глибокої шахти для дослізження надр Землі, утилізація теплоти ядра і політ за межі Землі.

Цікаво, що прочитані мною раніше фантастичні романи Жюля Верна і Г. Уеллса, написані безпосередньо на теми міжпланстних польотів, не справили на мене особливого враження - причиною цьому, мабуть, було те, що романи ші, написані менш талановито і блискуче, ніж роман Келлермана, були у той же час для мене явно неспроможними з науково-технічної точки зору.

Тема про глибоку шахту, після розробления основ деяких передпозитивних варіантів, дуже швидко наштовхнулась на неможливість для мене провссти відповідну експериментальну роботу, - тема $*$ про міжпланетний політ виявилась набагато вдячнішою $\mathrm{i}$ оволоділа мною на довгий час, протягом нкого $x$ неодноразово до неі повертався, поки не підійшов до межі, за котрою подальша плідна праця неможлива без паралельного експериментування.

Перший період роботи продовжувався більше ніж півроку і містив майже всі основні положення щодо ракетного польоту, які увійшли у видану пращю, але без детальної обробки і часто без точної матсматичної аргументації.

Згодом, з виданого у цей період абсолютно не були надруко- 
вані розділи V i VII і тільки у принципі надрукували розділи IV i IX, a y розділі VII через неглибоке знайомство з хімісю розглядався тільки заряд кисню і водню.

Основним матеріалом роботи щього періоду було виведення основної формули ракети (4), знаходження доцільнішої траскторії (розділ VI) і деякі загальні положення 3 інших розділів.

Націлившись на політ у міжпланетні простори, я одразу зупинився на ракетному методі, «ракетному» у загальному розумінні цього слова, згідно 3 визначенням, даним мною у розд. 1 , відкинувши артилерійський, як явно технічно занадто громіздкий, який не гарантує повернення на Землю і тому безглуздий.

Ще до виведення основної формули мною було приблизно розраховано декілька механічних варіантів, з яких найдосконалішим був швидкообертовий барабан 3 намотаним на ньому сталевим тросом, котрий повинен був розмотуватись у один бік, надаючи барабану протилежного прискорення; отримавши, звичайнодаючи одразу ж неймовірні значення необхідної ваги для ракети (п), я перейшов до комбінованого ракетно-артилерійського варіанту: я перейшов вистрілюе з себе ядро, котре в свою чергу є гарматою, яка вистрілюе ядро і т. д., і знов одержав страшні розміри початкового заряду, після цього я повторну гармату (тобто, перше ядро) повернув дулом назад, перетворивши їі у постійну частину ракети і примусив ї̈ стріляти у зворотний бік дрібнішими ядрами, тобто збільшив активну масу заряду за рахунок пасивних мас і знов одержав страшне значення для маси ракетної гармати, але тут помітив, уже, що чим більше збільшую масу активної частини заряду за рахунок пасивних мас (ядер), тим вигідніші одержую формули для маси цієї ракети - звідси неважко було логічно перейти до суто термохімічної ракети, котру можна розраховувати за формулою (4) ракети, до того ж, внаслідок зробленого мною при початкових підрахунках спрощення, потім забутого і пропущеного, в основі цієї формули деякий час було не 1 , а 2, і результати через цю помилку одразу одержувались надзвичайно обіцяючі.

Незабаром я знайшов і принципи найвигіднішого використання ракетної реакції - надання прискорення у найнижчій точц траскторії. Після виправлення помилки в основі (4), я одержав у результаті вже менш слушне значення «п» (відношення маси ракети до корисного вантажу), а саме - $\mathrm{B}=55$ без урахування ракети до корисного вантефіцієнті корисної дії і наявності пропорційних пасивних мас. Ця цифра 55 мене вже дуже тривожила, але шарм порушеної теми був таким, що сам себе обманюючи, я насильно вважав щю цифру сприйнятною до тих пір, поки не знайшов нарешті протидію цим 55 у вигляді фізико-математичного обгрунтування можливості благополучного спуску на Землю за
рахунок опору атмосфери, а потім у розвитку штучним шляхом початкової швидкості, організації міжпланетної бази і її ракетноартилерійського постачання. Іншим питанням, що мене тривожило, була необхідна за першим чисто ракетним варіантом відльоту, вельми значна сила реакції - не менше подвоєної сили тяжіння - це занепокоєння залишило мене пізніше - після знайденої можливості з вигодою використати при відльоті авіаційні крила, причому мінімальна припустима сила реакції зменшусться у декілька раз; нарешті, останнім питанням, що дуже турбувало мене, була метеорна небезпека - тільки декілька днів тому, отримавши від Я. I. Перельмана його книгу «Міжпланетна подорож», Я дізнався, що іноземні автори, які математично досліджували це питання, дійшли слушних висновків.

Досягнувши у 1917 році перших позитивних результатів, і не підозрюючи у той час, що я не с першим і єдиним дослідником у цій області, я на деякий час спочивав на лаврах у чеканні можливості приступити до експериментів, котрі розраховував одержати реалізацією винаходів, тримаючи між тим свою роботу у найсуворішому секреті, оскільки, враховуючи з самого початку велич $\mathrm{i}$ невизначеність можливих наслідків від виходу людини у міжпланетні простори, я у той же час наївно вважав, що досить опублікувати знайдені основні принципи, як негайно хто-небудь, маючи достатні матеріальні кошти, здійснить міжпланетний політ.

У 1918 році в одному зі старих номерів «Нивы» я випадково натикнувся на замітку про ракету Ціолковського, але «Вісник повітроплавства», на котрий посилались у замітці, я ще довго не міг розшукати.

Ця замітка і замітки, що траплялись мені згодом у періодиці про закордонні дослідження, дали поштовх подальшій точнішій i докладнішій розробці теорії польоту, для переходу від загальних фізичних принципів до обговорення технічної можливості і їнньому реальному застосуванню.

Беручись за роботу декілька разів з перервами між репетиторством, рубанням дров і роботою мастильника, мені вдалось до 1925 року доповнити їі майже до нинішнього ї̈ вигляду: у всіх розділах була проведена більш обгрунтована математична мотивація, підібраний досить повний хімічний матеріал, розроблено розділ VII про опір атмосфери при польоті, обгрунтована розрахунками можливість благополучнопо спуску і зроблені інші менш важливі доповнення.

У 1925 році, коли робота вже підходила до кінщя і коли мені вдалось, нарешті, розшукати «Вісник повітроплавства» за 1911 рік 
з частиною роботи К. Е. Ціолковського, я, хоч і був частково розчарований тим, що основні положення мною відкриті вдруге, але між тим із задоволенням побачив, що не тільки повторив попередні дослідження, хоча й іншими методами, але зробив також i нові важливі внески у теорію польоту. Головна відмінність методу моїх розрахунків з методом Ціолковського полягає в тому, що К. Е. Ціолковськиі у багатьох випадках виходить з роботи сил. Я ж всюди - винятково 3 швидкостей і прискорень: виходячи 3 того, що робота сил у реактивному питанні залежить від багатьох умов і позначається також досить по-різному, надані ж ними прискорення, а, отже, і швидкості, значно більш визначені, я вважаю «швидкісний» метод розрахунку легшим і продуктивнішим.

У 1926 році я одержав відгук професора В. П. Ветчинкіна, який буквально збентежив мене свосю високою оцінкою моєі роботи (за традицісю я від «професорів» заздалегідь не схильний був чекати нічого гарного), і з дня на день став чекати ї̈ видання, але потяглася обгрунтована доброякісна тяганина Головнауки i ГИЗу - розгляд, асигнування грошей i відбирання ї назад - це тривало два 3 половиною роки. На щастя, 3 машиністів мені до цього часу вдалося висунутись у механіки і конструктори, внаслідок чого я одержав можливістъ зібрати кошти на власне видання книги у Новосибірську, без чого невідомо коли побачила би світ моя праця. Головнаука відмовила не тільки у грошах на видання, але навіть у організаційній допомозі (видати за мій рахунок у пристосованій для наукових видань друкарні) - друкувати ж у журналах я не хотів, не бачивши можливості скоротити свою працю, і між тим, не розраховуючи на можливість надрукувати роботу повністю.

У 1927 році за порадою В. П. Встчинкіна я змінив узвичаєну систему позначень у частині термінологіі, вставив висновок Ф-4, який я не наводив раніше i виправив помилку Ф-6 (вплив мас пропорційного пасиву). Він же звернув мою увагу на величезне значення конструктивної розробки «горілки» - вихлопної труби, внаслідок чого я написав і вставив розділ VI.

Подальша плідна розробка теми про міжпланетний політ суто теоретичними мстодами, мабуть, неможлива, для мене у всякому разі: необхідні і експериментальні дослідження.

Час і гроші для них я розраховую одержати винаходами у різних галузях, зокрема, за родом моїх занять - у галузі елеваторної механіки: поки що я досягнув перших успіхів - недавно визнали мій новий тип елеваторного ковша.

Попутно надсилаю Вам класичний відгук одного вченого, який показус, що не перевелись ще «зубри», котрі будуть 3 тупою упертістю лаяти ідею міжпланетного сполучення, як і всяку нову ідею, до тих пір, поки не буде встановлене регулярне сполучення зі світовими просторами і поки холодні країни не будуть обігріті перехопленими за тисячі верст від Землі сонячними променями...
3 повагою
Ю. Кондратюк

1.V.1929 p.

\section{7. Рядки $з$ листа К. Е. Ціолковському}

Здивований ... схожістю наших думок з багатьох різних питань...

Моє клопотання про організацію підприсмства для надання коштів для міжпланетних сполучень митарствує у Москві безрезультатно (30.03.1930 p.).

3.8. Дані $з$ анкети для заарештованих $\mathrm{i}$ затриманих з зарахуванням за ОдПу (30.07.1930 p.)

ондратюк Юрій Васильович, громадянин РРФСР, національність великорос, походить 3 Волинської губсрнії, міста Луцька, вік 30 років, народився у 1900 році, освіта середня, закінчив 7 класів гімназії, одинокий, безпартійний, механік, пом. райінженера Сибконтори «Хлібобуд», навчався в школі м. Луцька до 1918 р.

До 1922 р. - на млині Зинов. округу - мастильник;

до 1926 р. - цукровий завод - мастильник-механік;

до 1927 р. - елеватор Північкавказ - механік;

до 1930 р. - Сибконтора «Хлібобуд» - пом. райінженера. Чи притягався до відповідальності по суду або у адміністративному порядку - ні.

Відношення до військової повинності - стою на обліку.

Коли заарештований -30 липня 1930 р.

Ким заарештований, по чисму ордеру і № oрдеру - ОДПУ, ордер № 895 .

Де заарештований - м. Новосибірськ.

Чи пред'явлено звинувачення і у чому саме - по ст. 58-7.

Місце проживання - м. Новосибірськ, вул Максима Горького, 120. Офіційна назва місця ув'язнення - ОДПУ. 


\section{9. Витяги 3 протоколів допиту (1930р.)}

а запитання про шкідництво, проявлене у будівництві мехамбарів за явно непридатними проектами Правління «Союзхліб» повідомляю таке: наскільки мен відомо, думка про необхідність механізації колишніх «наркомпродівських» амбарів... виникла при відвіданні «Алтайської гілки інженером Правління Сивохіним, у зв'язку 3 майбутнім будівництвом елеватора 1927 р... Тоді і було підняте питання про необхідність механізації, причому у завдання механізації була поставлена тільки засипка зерна у силоси 3 прийомки... Чому завдання механізації не було поставлене ширше - не знаю.. Горчаковим і мною Правлінський проект був розкритикований, як проект, котрий 3 одного боку ставить собі надто вузьке завдання, 3 іншого боку - може бути вельми здешевленим, якшо зберегти ті ж дві норми для двох половин амбару, розташувати ї не поза планом корпусу, а усередині його, причому одночасно цим вирішується і завдання відвантаження і зваження зерна. Для можливості перенесення механізмів всередину корпуса пристрою самопотоку у них і з силосів, і з залишених зовні завальних ям, без застосування масивних робіт під готовою спорудою, - нами були спроектован 2, наскільки мені відомо, принципово нові елементи, які до тих пір у нас ніде не застосовувались: перший - пропускання самопливів зерна крізь грунт і другий - пристрій тонкостінного колодязя круглої форми, не зважаючи на його досить глибоке закладання і значне навантаження від грунту.

У 1928 р. нам доручили механізувати клюквенські два амбари Союзхліба, смністю кожен у 100 тис. пудів, за проектом, надісланим з Правління Союзхліба... Проект був вельми невдалим і щодо дорожнечі обладнання, і щодо експлуатації. (Абсолютно не передбачена зручність прийомки). Цей проект ми відкинули, обидва амбари ми об'єднали в один, i, застосувавши до нього принцип механізації 27 року плюс баштові відпускні силоси і вагонеточна прийомка та, частково обладнавши його лійкоподібними днищами, ми одержали вже цілком задовільну елеваторну одиницю.

..Вважаю, що невдалість проектів, які надсилались нам Москви, походила від невміння підійти до цього нового тоді завдання і від невміння дати шо-небудь нове зверх американських стандартів. Всякі нововведення взагалі i всюди, як правило... зустрічають з боку фахівців більш-менш стійкий опір. Так сталось і 3 його проектом елеватора Сибірського типу; як вже відзначалося тут, окрім новизни, опір викликало те, що він підривав престиж правління «Хлібобуду», котре висловлювало численні заперечення і докази його «дефективності», частково малоістотні, частково помилкові, з одночасним замовчуванням його переваг.

Основна результативна різния між канадським і

типами елік канадським і сибірським у значно елаторів ємкістю 1600 тонн за проектами 1929 р. полягає інасо меншій вартості другого (100 тис. проти 150 тис. крб при елеваторі Сиб умовах і 3 урахуванням установки у Сибірському елеваторі Сибірського ж обладнання господарчого виготовлення) за рахунок скорочення потреби найбільш дефіцитних матеріалів i більшій оперативній потужності його щодо відвантаження і застосування зручнішого і дешевшого способу прийомки зерна вагонетками.

На задане мені питання про шкідництво, виявлене у елеваторному будівництві в Сибіру, можу сказати, що у тій частині сибірського елеваторного будівництва коти, що у тій частин тобто у елеваторному будівницицтва, котра мені добре відома, «Союзхліба» - «лібобуду», наскільки мені відомо, за моім твердим переконанням, шкідництва не було; за лінію центру детально не знаючи його апарата, ручатися не можу.

\subsection{0. Уривки з технічних довідок до проекту вітроелектроустановок (1932-1938 рр.)}

ерші пропозиції щодо проектування потужного Головенерго у травні 1932 горегата надійшли 3 планового відділу А. П. Дзюби, який Новосибірську, Ми знав нашу ініціаторську технічну роботу у Новосибірську. Ми від цієї роботи спочатку відмовились почасти із-за скептичного ставлення до неї, почасти через нестачу часу. Однак, ознайомившись із загальним становищем вітчизняної вітротехніки ми зробили деякі попередні розрахунки і конструктивні скетчі, i, отримавши повторні пропозиціі, погодилися взяти участь у цій роботі, і у вересні 1932 року підписали угоду на складання ескізного проекту строком на два місяці (як ми згодом дізналися, інститутам на те ж саме давались строки у півроку і суми порядку 50000 рублів).

Залучивши до проектування відомих нам у Новосибірську талановитих конструкторів,... ми зробили проект за два місяці, значно перевиконавши проектне завдання поскт за два місяці, зультат частково за рахунок дрийнятого дешо одржали такий ревітроколеса,... а головне . вітроколеса,... а головне, за рахунок вдалого рішення конструкціі
башти великої висоти... 
У листопаді 1932 року на засіданні Головенерго була представлена зведена доповідь про проекти, в яких з'ясувалися дві речі: 1) наша технічна перевага відносно масштабів проекту, відносно техніко-економічних показників його $\mathrm{i}$ відносно оригінальності $\mathrm{i}$ економічності технічних рішень цілого ряду питань і 2) вкрай нездорова атмосфера конкуренції і недоброзичливості з боку Центрального вітроенергетичного інституту, котрий у технічному відношенні опинився у хвості всіх проектів. Потім почалась експертиза проектів найсильнішими фахівцями з Москви і Ленінграда, організаційні заходи по експертизі проводились 3 нескінченними затримками і перешкодами.

1. Питання щодо паралельної роботи вітросилового агрегата дозволено втілювати 3 усіх проектів тільки нам.

2. Запропонована нами оригінальна конструкція високої вежі досить ефективно відображається на перспективах потужного вітровикористання у цілому, і хоч викликає чимало страхів, - але жодного технічного заперечення.

3. Інші елементи, вилучення частого застосування тросів у конструкції вітроколеса (від чого ми тепер відмовились), не зустріли заперечень і були оцінені як принципово правильні.

Після Головенерго мала місце наша особиста доповідь Наркому тов. Орджонікідзе. Ознайомившись додатково зі станом питання нашою роботою, Нарком дав розпорядження на розробку технічного проекту. Для нашого організаційного оформлення, а також щоб дати подальший розвиток технічним концепціям Українського інституту променергетики, було вирішено прикомандирувати нас до щього інституту.

Участь Українського інституту променергетики у нашій роботі звелась до того, що ми обговорювали організаційні потреби обох вітросекцій. Запропонований нами Головенерго на початку січня вітросекцій. Запропонований нами Головени завершення інсти1934 року проект спочатку пролежав, чекаючи завершення інститутського проекту, а потім був направлений

Нарешті у квітні, з приїздом у Ленінград інженера Горчакова, експертизу було організовано. Закінчила вона роботу до 1 липня 1934 року, було дано нашому проекту цілком позитивну оцінку. По нашій повторній доповіді Наркому тов. Орджонікідзе було зроблено розпорядження про надання коштів на робочий проект. Оформлення надання коштів у апараті Головенерго тягнулось до жовтня 1934 року. В жовтні 1934 була організована наша проектно-будівнича контора.

Вітер є одним 3 найбільш розповсюджених і потужних джерел енергіi. За своєю потужністю 3 доступних у теперішній час для рентабельного використання джерел енергії вітер поступсться лише сонячній енергії. Справа тільки за створенням рентабельної конструкції достатньо великих вітросилових установок.

Вітросилові ресурси настільки величезні, що ї не можна повністю освоїти навіть і у перспективі...

Таким чином, для ряду великих районів вітроелектростанції можуть дати дешевшу енергію, аніж теплові станції, не вимагаючи великих капіталовкладень на той же річний об'см виробки енергії. Вітроелектростанції у багатьох випадках вигідно будувати навіть для однісї тільки економії палива.

Збільшення виробки енергосистеми майже скрізь значно вигідніше досягти побудовою вітроелектростанції, а не ГЕС, оскільки при майже рівних капіталовкладеннях ВЕС повністю економить теплову складову. Тому вони можуть і повинні зробитись вітровими Дніпрогесами, 3 великою перевагою на користь вітру, як відносно розміру капіталовкладень, так і відносно строків введення до експлуатації. Передбачається і хімічне акумулювання енергії шляхом електролізу води. Кисень разом 3 паливом подають у топку котла теплової станції або циліндра дизеля, у результаті чого виходить енергія і чиста вуглекислота.

Оскільки, зважаючи на усі дані, вітроенергетиці у нашому народному господарстві належить у недалекому майбутньому значна роль, необхідно організувати термінове будівництво невеликих $(100 \mathrm{kBT})$ вітросилових станцій з усім комплексом, що відноситься до цієї справи заходів - створенням виробничо-експериментальної бази, проведенням необхідних досліджень, експериментів.

Попутно і негайно, услід за реалізацісю станції на $100 \mathrm{kBT}$, треба приступити до проектування потужніших вітродвигунів $\mathrm{i}$ розвиненіших веж (за типом Уфімцева-Встчинкіна), для того щоб до кінця третьої п'ятирічки були готові конструкції вітросилових агрегатів потужністю до 1000 кВт для середніх вітрових умов.

\subsection{1. Експромт Ю. Кондратюка (1938 р.)}

Оритінал

Український переклал

Женщин я не признаю,

С детства я Луну люблю.

О свиданьи с ней мечтаю,

Экипаж изобретаю...

Полечу я к ней в ракете,

Словно в собственной карете.
Я жінок я не визнаю, Змалку Місящь я люблю. Щоб здійснить туди вояж, Винаходжу екіпаж... I до нього у ракеті, Полечу, мов у кареті. 


\subsection{2. Замітка (20.06.1938 р.)}

Течуть роки... Течуть радянські гроші... В повітрі 3 вітром проносяться мільярди невикористаних кіловат-годин, а у цей час справа промислового вітрокористування внаслідок байдужості і безвідповідальності повзе і спотикаєтся так, що... важко навіть розрахувати - рухається воно уперед, чи зовсім що... важко на місиі... Кожен рік зупинки дає нам величезні паливні і транспортні втрати.

\subsection{3. Відповідь на лист О. М. Горчакової}

1 вересня $1941 \mathrm{p}$.

Мила Ольго Миколаївно. Ви мене дуже порадували листом - це єдине, що я досі маю. Дуже радий, що Ви вали листом - це сдине, що я досі маюско. Мене дуже турбують кияни, враховуючи (тут декілька слік викреслено військовою цензурою), ке маю. Буду справлятись через домоуправління що від них нічого не маю. Буду справлятись через домово і там-то знаходимось.

Все, що до мене зараз доходить 3 «зовнішнього світу» - це іноді вдається 3 гучномовця почути хвилин п'ять музики 3 Москви Поезія теж поступово набридає, особливо коли вона підноситься зовсім не у чистому вигляді.

Моя нова адреса: Діюча армія. Польова пошта № 930.62 стрілещький полк. Червоноармійцю роти зв'язку - мені. Про мене не турбуйтесь, зі мною, звичайно, нічого не трапиться. Спасибі за Ваш теплий лист. Міцно, міцно цілую.

Дійсно, все робиться у житті навпаки. Привіт Люсі і всім. Уточніть мені номер Вашого телефону И-07290 чи 02790 - я вжс не впевнений. Ще раз міцно цілую. Юр. Пишіть хоча 6 потрошку. Це для мене велика радість. Юр.

\subsection{4. Листівка Ю. В. Кондратюка}

до Г. П. Плетньової

орога моя Галушенька, мене дуже турбує твос мовчання. Напиши негайно. Зі мною, як завжди, все благополучно. Повторюю адресу: 968-ма польова пошта, стрілецький 1281-й полк, 1-й батальйон, взвод зв'язку, мені. Міцно, міцно цілую і чекаю листів. Юр.

\section{4. ПЕРЕЛІК ОПУБЛІКОВАНИХ I РУКОПИСНИХ ПРАЦЬ Ю. В. КОНДРАТЮКА (О. Г. ШАРГЕЯ)}

\section{1. Опубліковані твори}

Патенти на винаходи $\mathbf{i}$ авторські свідоцтва -10

Статті у журналах:

«Горний журнал» -4

«Социалистическая индустрия» -1

«лектрические станции» - 1

Книги:

«авоевание межпланетных пространств». - Новосибірськ, 1929.

«Завоевание межпланетных пространств». - М.: Оборонгіз, 1947.

«Завоевание межпланетных пространств». «Тем, кто будет читать, чтобы строить: Избранные труды. - М.: Наука, 1964.

\section{2. Рукописи, які збереглися}

Рукопис без заголовка, у чотирьох зошитах, зшитих в один, 104 сторінки рукописного тексту, написаного олівцем. Ю. В. Кондратюк. Датований 1916 р. Зберігається в Інституті історіі, природознавства і техніки РАН. Автограф (19141917). У цьому виданні названий «Полтавсько-петроградський рукопио.

«Тим, хто буде читати, щоб будувати» Ю. В. Кондратюк. Рукопис 144 сторінки. Датований 1916 р. Зберігається в Інституті історії, природознавства і техніки РАН. Автограф (19181919).

Рукопис без заголовка, написаний чорним чорнилом на 79 сторінках. Ю. В. Кондратюк. Спочатку датував його 1920 р., проте потім дописав: «переписаний і відредагований у 19231924 рр.» Один 3 примірників цього варіанту рукопису був у 1925 р. направлений на рецензію В.П.Вєтчинкіну, який i назвав статтю «Про міжпланетні подорожі». Зберігається в Інституті історіі, природознавства і техніки РАН. Автограф (1925).

Два примірники машинописного тексту роботи «Завоювання міжпланетних просторів». На 66 сторінках 3 рукописними встав- 
ками і примітками. Це передрукований на машинці текст ками і про (третього) варіанту з урахуванням зауважень, зроблених В. П. Встчинкіним (додано розділ «Процес згоряння, конструкція камери згоряння...», дещо змінені позначення і термінологія, додано виведення основної формули польоту ракети). Один з цих примірників був у 1927 р. відредагований В. П. Вєтчинкіним і підготовлений до друку.

\section{5. СТОРІНКИ ЖИТТЯ ГЕНІЯ (Біографія Ю. В. Кондратюка - О. Г. Шаргея)}

езвичайна, складна, трагічна і водночас прекрасна доля вченого-самоука. Ніякі примхи життя не могли перешкодити Ю. В. Кондратюку створювати основи космічного світогляду і космічної техніки.

Треба відмітити, що протягом багатьох років біографія і наукові праці О. Г. Шаргея (Ю. В. Кондратюка) не були відомі широкому загалу. Твори його були відомі лише вузьким науковим колам, а його б́іографія, точніше окремі епізоди 3 життя, - ще меншій кількості людей.

Громадсько-політичні обставини у СРСР ніяк не сприяли відновленню доброго імені Ю. В. Кондратюка, репресованого 1930 році і не реабілітованого до 1977 року, який змінив у 1921 році ебілогвардійське» прізвище О. Г. Шаргея на інше і який не має точного місця поховання у війні $1941-1945 \mathrm{pp}$.

Слід відмітити, а це підтверджують біографи косміста А. В. Даценко, і Б. І. Романенко, що чуже прізвище по-справжньА. В. Даценко В Кондратюка. Про це він говорив своїм ому обтяжувало Ю. В. Кондратюка. По золо, збирався «піти 3 друзям і близьким, які знали його історію, збирався жпіти 3 повинноюз у ОДПУ. Але його друзі, пам'ятаючи жорстокість і несправедливість 1930 років і прекрасно розуміючи поліцейський характер держави, у якій жили, умовили Юрія Васильовича не робити цього вчинку.

Після громадянської війни його могли розстріляти як білогвардійського офіцера, у 1930-ті роки - як прапорщика білої арміі, який приховував своє «істинне обличчя», а після смерті C. Орджонікідзе - як такого, що працював під його протегуванням... У роки Вітчизняної війни ним міг зацікавитися «СМЕРШ ... I у всіх цих випадках вченого могла спіткати сумна доля. Тому Ю. В. Кондратюку довелось у житті від багатьох речей відмовитися, у тому числі, від зустрічей з родичами, від одруження, від улюбленої справи (від роботи у ГВРР)...

у довоснні і повоснні роки на його імені лежало вето, як на репресованому і реабілітованому.

I тільки наприкінці п'ятдесятих років, після запуску першого штучного супутника Землі (4 жовтня 1957 року) різко зріс інтерес до космосу, космонавтики, до історіі космічної науки. Тоді i почалася серйозна пошукова робота, спрямована на вияснення істинної біографї̈ Ю. В. Кондратюка i його вкладу у теорію космонавтики. У цій праці брали участь Альошкін А. М., Встчинкін В. П., Воробйов Б. М., Глушко В. П., Горчакова О. М., Даценко А. В., Даценко О. В., Сфімов Л. Л., Жук В. Н., Іващенко В. Н., Лашинська-Маркевич Т. І., Ліфшиц Л. А., Ляпунов Б. В., Меркулов І. О., Мігіренко Г. С., Писаренко Г. С., Победоносцев Ю. О., Рапnопорт А. Г., Раушенбах Б. В., Романенко Б. І., Романська О. Д., Севастьянов В. І., Сокольський В. М., Сорока Н. А., Тросніков В. Н., Чернишов Н. Г. та інші.

Однак, доводиться визнати, що воскресіння імені Ю. В. Кондратюка було декому не до вподоби, оскільки його визнання зменшувало славу вже визнаних світил науки космічного напрямку.

Серед інших «сенсацій» про Юрія Кондратюка була і версія про те, що частина рукописів вченого, а саме «останній зошит», потрапив до рук німецького конструктора-ракетчика Вернера фон Брауна, який після розгрому гітлерівської Німеччини став провідним конструктором ракетно-космічного комплексу США. Поширювалися чутки, що якийсь Кондратюк працював у фон Брауна. Але згодом вияснилось, що це - однофамілець Кондратюка, який у його рукописах розібрати нічого не зміг.

Брат Ю. В. Кондратюка А. В. Даценко звернувся з проханням прокоментувати цю версію до Георгія Олександровича Тюліна, який у 1945-1946 роках очолював колектив спеціалістів, що вивчали трофейну ракетну техніку. Г. О. Тюлін розповів, що у складі комісії «були відомі нині вчені і конструктори Ісаєв, Черток, Бармін, Рязанський, Пілюгін, Побєдоносцев, Глушко, Чернишев, Корольов; у жовтні склад комісії перевишив 100 чоловік, причому 
більша частина знаходилася у Тюрінгії, потім у Берліні. Тюрінгія зацікавила тим, що там, у районі містечка Кордхаузен, були розташовані підземний завод по витотовленню ракет, інші дрібні підприємства і великий концтабір «Дора» для військовополонених... Більше ніж за півтора роки була проведена велика робота, опрацьовані численні документи i, думаю, якби серед них опинився «зошит Кондратюка», або які-небудь інші його документи, ми обов'язково знали б про це. I Глушко і його співробітники не пропустили б цих матеріалів. Чого не було, того не було. Це підтверджуе і інша обставина. Якщо б до фон Брауна потрапили зошити Кондратюка, або він сам вирішив піти на контакт 3 німецьким вченим, то, імовірно, США не віддали б пальму першості при запуску першого ШСЗ Радянському Союзу, оскільки у цих роботах було багато того, що могло прискорити запуск першого американського ШСЗ.

Так була відкинута ще одна версія, що якоюсь мірою плямувала ім'я вченого.

Біографія Ю. В. Кондратюка i його діяльність до сьогоднішнього дня, ше мало відомі більшості громадян України, країн СНД, та мабуть і в усьому світі.

Жоден автор проектів або друкованих праць 3 космізму не робить посилання на Ю. В. Кондратюка. Або вони не читали його праць, або не бажають визнати його пріоритет?

Так, наприклад, 4 лютого 1993 року в Російській Федерації під керівництвом професора В. Сиромятникова проводився екперимент, який був описаний у 1919 році 22-річним О. Шаргеєм, передачі 3 космічної орбіти на Землю сконцентрованого сонячного світла. «На жаль, - писав Лесков, - ні В. Сиромятников, ні інші нічого не сказали про ці ідеї $\mathrm{i}$ конструкторські пропозиції Ю. В. Кондратюка. Можливо, вони до цього часу не читали його пращь. Прикро. І нс випадково мені наприкінці березня 1992 року академік Б. В. Раушенбах сказав: «А ви думасте, що навіть зараз хто-небудь $з$ академіків читас Кондратюка?»

Не читають не тільки академіки, але й інші спеціалісти. Так, у збірнику тез науково-технічної конференції «Аерокосмічний комплекс: конверсія $\mathrm{i}$ технологї̈, виданому у 1995 році Житомирським інженерно-технологічним інститутом, у тезах доповіді «Космізм, як філософія XX сторіччя» (доповідач I. Д. Батіна) не названі космісти Ю. В. Кондратюк, О. Л. Чижевський, проте наведено ряд маловідомих прізвищ.

Так і виникло поживне середовище для різних чуток, плямувань. Головне - закласти крихітку сумнівів. А вже ті, 3 чиєю допомогою ця крихітка розростеться у вагому підозру, знайдуться.
I плювати їм на те, що залишається закритою одна з яскравих і славних сторінок історії нашої вітчизняної науки.

Такі причини того, що про Ю. В. Кондратюка довгі роки не писали і намагалися не згадувати.

Відомо, що книга Ю. Кондратюка «Завоевание межпланетных пространств» була однією з настільних книг С. П. Корольова, В. П. Глушка та інших радянсьних діячів космонавтики...

Припустимо, у минулі часи, при тій ситуадії в СРСР не рекомендувалось посилатись на «недозволених» людей. А сьогодні? Відрадним с те, що українські вчені Я. С. Шифрін, В. М. Шокало, В. І. Ломан та інші автори проекту «Передача енергії на відстані», вважають себе співавторами Ю. В. Кондратюка в цій роботі.

Так, дійсно, ще залишився ряд жбілих» плям в житті i діяльності великого косміста, у тому числі:

- місце поховання бійця взводу зв'язку першого батальону 1281-го стрілецького полку, польова пошта 968, який загинув під час війни 1941-1945 років;

- зошити та креслення передвоєнного часу 3 заповітними думками вченого і технічними рішеннями нових відкриттів.

\section{Основні дати життя косміста-піонера космонавтики}

1897 р., 9 (21) червня. У м. Полтаві у флігелі будинку № 4 по Срітенській вулиці (нині Комсомольській) Людмила Львівна Шаргей (в дівоцтві Шліппенбах) народила хлопчика, якого назвали Олександром. Батьком майбутнього піонера космонавтики був Гнат Бенедиктович Шаргей.

1900 р., 8 вересня. У Луцьку народився Георгій Васильович Кондратюк.

1903 р. Мати Олександра Шаргея Людмила Львівна через душевну недугу потрапляє у лікарню, де вона і померла на початку 1910 року. Маленького Сашка батько залишив під наглядом матері - Катерини Кирилівни і вітчима - Акима Микитовича Даценка.

3 дитинства Сашко захоплювався механікою. Він розбирав i знову збирав або ремонтував різноманітні побутові прилади. Не забував він і про дитячі ігри. Коли прийшла пора навчання, для Сашка найняли приватну вчительку Катерину Феліксовну Свосхотову, яка вирізнялась не тільки енциклопедичними знаннями, особливо 3 природничих i точних наук, але і педагогічним тактом. Приватне навчання 
було викликане тим, що у 2-гу гімназію, орієнтовану не тільки на гуманітарні, але і точні науки, де бажав навчатися Сашко, приймали дітей дворян.

1910 р., 23 липня. Смерть Гната Бенедиктовича Шаргея, батька О. Г. Шаргея.

1910, 14 вересня-1916, 28 травня. Навчання О. Г. Шаргея у 2-й Полтавській міській гімназіі. «Він мав чудові здібності у галузі математики i iнших точних наук,» - згадував колишній учитель гімназії В. С. Огоневець. Навчальний процес у гімназії був спрямований на самостійне вивчення наукових істин. Передбачались позакласні читання і лабораторні роботи. Сашко став одним 3 краших учнів у класі. Але найбільше уваги він приділяв точним наукам, особливо математиці. А у вільний час він пробував вирішувати глобальні проблеми. Познайомившись 3 ідеями польоту на Місяць Ж. Верна (« гармати на Місяць») та Г. Уелса («Перші люди на Місяці»), хлопчик піддав іх сумнівам, а у 16 років дійшов висновку, що це завдання можна вирішити за допомогою ракет.

1913-1916 рр. Початок наукових досліджень О. Г. Шаргея в галузі міжпланетних подорожей. Олександр Шаргей, 16-19-літній юнак-гімназист, не маючи вищої освіти, самостійно логічно і науково-технічно обгрунтував можливість і необхідність занюювання космічного простору у мирних цілях. Так він став основоположником космічної філософії, який увійшов у історію під іменем Юрія Васильовича Кондратюка, в силу обєктивних причин змінивши прізвище. За перші півроку 17-літній юнак у одному шкільному зошиті сформулював i математично обгрунтував можливість реактивного польоту, визначив швидкість, необхідну для подолання земного тяжіння і вирішив ряд інших питань.

1916 р., 10 червня. О. Г. Шаргей зі срібною медаллю закінчує Полтавську гімназію.

1916 р., 1 вересня-11 листопада. Навчання на механічному відділенні Петроградського політехнічного інституту. Закінчив першу свою працю, викладену на 104 сторінках рукописного тексту (4 шкільні зошити). Але в них вже були закладені основи майбутніх геніальних рішень.

1916 р., 24 листопада. О. Г. Шаргея призивають на військову службу і направляють на курси прапорщиків при одному з юнкерських училищ Петрограда.

1917 р., березень. О. Г. Шаргей закінчує школу прапорщиків при Петроградському юнкерському училищі.

1917 р., березень-1918 р., квітень. Командир взводу на Закавказькому фронті (Туреччина).

1917 р., квітень. О. Г. Шаргей закінчус роботу над першим рукописом 3 міжпланетних подорожей (рукопис - варіант № 1).

1918 р., квітень-березень. О. Г. Шаргей після заключення Брестського миру демобілізований і направляється в Полтаву. На шляху із Закавказзя в Полтаву насильно мобілізований у білу армію, а потім тікас 3 неї.

1918 р., травень-червень. У травні Олександр добрався до Полтави, але будинок Даценків спорожнів: Катерина Кирилівна померла, а дідусь Аким Микитович, тяжко хворий, виїхав у рідне село до сестри. У місті господарюють німецькі окупанти. Олександр переховусться у товариша по гімназії Миколи Скриньки, у багатій бібліотеці якого він наштовхнувся на журнал «Нива» 3 заміткою про раксти Ціолковського для польоту за межі Землі. I знову спалахнула пристрасть до роботи. Він почав поглиблювати свої попередні дослідження. 1918 р., червень-1919 р., жовтень. Київ. Тут, 3 червня 1918 року
Олександр проживас у свосі мачухи і працюе на різних роботах (вантажник, електрик, репетитор...). Оцінивши достоїнства і недоліки своеї першої праці, Олександр восени 1919 р. завершус їі, як досконалішу, багатопланову. Ці 144 сторінки, доповнені 6 сторінками передмови, і склали рукопис за назвою «Тим, хто буде читати, щоб будувати».

У цій праці отримали подальший розвиток питання як найекономнішого вильоту снаряда 3 Землі, так і конструювання таких снарядів і ї двигунів. У тому числі - питання стабілізації і управління польотами з використанням гіроскопів, застосування шлюзу i скафандра для виходу у відкритий космос, маючи при собі запас повітря. Автор розглянув питання використання сонячнї енергії як для опалення корабля так і для утилізації ї̈ на Землі; а також використання дзеркал ждля бездротового телеграфу».

Запропоновано найбезпечніше розташування членів екіпажу при впливі прискорення. Враховувався перегрів снаряда при польоті у атмосфері на великій швидкості і можливість аеродинамічного спуску. Також запропоновано використовувати сили тяжіння небесних тіл для корекції польоту. Вказано, що вигідніше для зупинки на небесних тілах користуватися не усім снарядом, а «пустити його супутником, а самому з такою частиною снаряда, яка буде необхідна для зупинки на планеті і зворотного присднання до снаряда, здійснити щю зупинку.» Розглянуто використання позаземних проміжних баз і економність такого підходу.

Таким чином, у цьому рукописі містяться усі основні 
передбачення Кондратюка по етапах розвитку космонавтики, 3 теорії i практики їх реалізації. Тут вперше точно сформульована ідеологія «Траси Кондратюка», яка використовує як сили тяжіння небесних тіл, так і посадочний модуль. Але у серпні 1919 року Київ захопили денікінці і під страхом розстрілу провели нову мобілізацію. Мобілізують і О. Шаргея. І знову - втеча з білої армії.

1919 р., листопад-1921 р., початок. О.Г. Шаргей переховується і працює мастильником вагонів на залізничній станції Бобринська (м. Сміла) і розпочинас роботу над третім варіантом свого рукопису, який пізніше назвали «Про міжпланетні подорожіs.

1921 р., початок. Працює на маслоробні і паровому млині у Малій Вісці.

1921 р., 1 березня. Смерть Георгія (Юрія) Васильовича Кондратюка.

1921 р., 15 серпня. Передача Олександру Шаргею документа, який засвідчував особу Г. В. Кондратюка. Віднині Олександр Шаргей починає свій життсвий шлях в Малій Вісці під іменем Георгія (у православному написанні - Юрія) Васильовича Кондратюка. Олександр Шаргей став на військовий облік як рядовий - Юрій Васильович Кондратюк.

1921 р., середина-1925 р., вересень. Працює кочегаром, машиністом, механіком на маловіскінському цукровому заводі. Але не так вже і просто жити під чужим іменем. I у червні 1922 року він відправляється у Київ, щоб продовжити свою освіту і побувати на батьківщині своєї матері. Це була його остання подорож під своїм справжнім іменем.

Через чотири місяці, не здійснивши своєї мрії, він повернувся у Малу Віску хворий на тиф. Нелегким моральним тягарем лягло на Олександра нове ім'я. Відокремившись від свого ебілогвардійського минулого, він у той же час ніби зрікся своїх предків. Та й з'являтися під новим іменем у тих місцях, де його знали як Олександра Шаргея, було теж небезпечно.

Закінчивши у цей час роботу над третім варіантом рукопису («Про міжпланетні подорожі» - так назвав ії пізніше професор В. П. Вєтчинкін), він, нарешті, ознайомився 3 частиною роботи К. Е. Ціолковського «Дослідження ся 3 частиною роботи К. Е. Цілковського Юрой Кондратюк побачив, що він повторив ряд результатів К. Е. Ціолковтюк пом ського. Але вияснив і те, що отримав ці результати іншим шляхом. Крім того впевнився, \&...що зробив також новий важливий внесок у теорію польоту». Загалом ця праця, повторюючи основні напрямки попередніх рукописів, не торкасться цілого ряду ідей, викладених у них. Ширше застосовані математичні обгрунтування, написаний ряд нових розділів. Написанню цієї праці сприяли систематична i глибока самоосвіта. Завершуючи роботу, Юрій Кондратюк у передмові до неї відмічає пріоритет К. Е. Ціолковського у вирішенні основних питань міжпланетних сполучень. Рукопис «Про міжпланетні подорожі» (червень 1925 р.) відіслано у Головнауку.

1922 р., листопад-1925 р., серпень. Олександр Шаргей повертається у Малу Віску. Пращюс на цукровому заводі на різних технічних посадах. У цей період він продовжує працювати над третім рукописом «Про міжпланетні подорожі». У червні 1925 р. пише першу передмову до цієї роботи і після цього направляє рукопис ії у Москву, в Головнауку, для рецензування і видання.

1925 р., жовтень-1926 р., жовтень. Ю. В. Кондратюк працюс механіком на будівництві зернового елеватора на станціі Криловська Північно-Кавказької залізниці (Ростовська область). Працюючи на елеваторі, він багато часу приділяс механізадії роботи і подає свої перші заявки на винаходи: «Пристрої для навантаження зерна у вагони» $\mathrm{j}$ « Лічильник до автоматичних вагів на елеваторі». На ці і ряд інших винаходів він отримав згодом патенти.

1926 р., 12 квітня. Ю. В. Кондратюк отримуе високу одінку своєї роботи «Про міжпланетні подорожі» (рукопис - варіант № 3) від інженера-механіка В. П. Вєтчинкіна. У відгуку детально проаналізований рукопис, показано, у чому він повторюе інших авторів, розглянуті інші цінні пропозиції стосовно керування ракетою i добре продумана програма експериментів та досліджень для підготовки і польоту ракети у Всесвіт. Вєтчинкін зауважив, що Кондратюк не знав досягнень зарубіжних вчених і навіть основних праць К. Е. Ціолковського. Позитивний відгук і доброзичливий особистий лист В. П. Ветчинкіна, а також запит секретаріату Л. Д. Троцького про згоду на роботу в одному 3 дослідницьких інститутів, надихнули Кондратюка. Продовжуючи роботу з модернізації елеватора, він знову займається космічними проблемами.

1926 р., Квітень-1927 р., квітень. Ю. В. Кондратюк працюс над четвертим варіантом свого рукопису «Про міжпланетні подорожі» 3 урахуванням побажань i зауважень інженера-механіка В. П. Встчинкіна, вже під заголовком «Завоювання міжпланетних просторівs. 
Восени 1926 р. нічне безсоння подвижника космічних досліджень вилилося у відкоректований рукопис «Завоювання міжпланетних просторів». Він був доповнений розділом Процес згоряння. Конструкція камери згоряння і вихлопноі труби». Старі розділи були дещо відкоректовані стосовно термінології, відновлено виведення основної формули ракети. термінологіі, відновлено виведення основно форм - після вип «Рукопис завершувався тверджснням: «Можна - після вип робування відповідних розмірів предметів пропорційного пасиву перейти прямо до польоту з людьми у міжпланетний простір - -3 обльотом, наприклад, навколо Місяця 3 невідомого нам його бокув.

Відправивши рукогис до Москви, Ю. В. Кондратюк чекав вістей як про його долю, так і про можливість переводу до Москви. Але відповіді не було. Сьогодні точно відомо, що на Москви. Але відоваріату Троцького про перевід Ю. В. Коннагады дратюка в .АГ «тов. В. П. Вєтчинкін ... не пропонував переводити иого для роботи в дослідницький інститут, тим більше, що тов. Кондратюк не має достатньої підготовки для ведення науково-дослідницької роботи. Зокрема, питання про міжпланетні подорожі не стоїь ще на черзі... Мова йде про переїзд ... у подин 3 великих центрів на роботу за його спеціальністю (на сдерат). I це не дивлячись на те, що В. ГІ. Ветчинкін рекомендував: «Його треба ... перевести на роботу у Москву... Тут його таланти будуть використані краше, ніж на елеваторі. Такі великі таланти-самородки дуже рідкісні і залишити іх без уваги 3 погляду держави було б виявом безгосподарності! Нарешті, майже перед самим від'їздом на будівництво нового елеватора, першого у Європі спеціально для кукурудзи, оснащеного спеціальними приладами, Конддатюк отримав листа з заміткою із газети «Вечерняя Москва» рал 07.10 .1926 р: «Новий проект міжпланетних подорожей у від роботі молодого раднско Кченотюка «Про міжпланетні подорожі».

Автор висловлюе у ній ряд міркувань про будову і деталі польоту ракети, яка призначена для міжпланетних сполупел Ознайомившися з працею, Головнаука визнала, що він чень. Ознайомивщї які є результатом вивчення питання автором. Однак, на думку Головнауки, питання про витотовавт мо моти значення лише при лення такоі ракети поки що може мати зоме литаріодослідженні верхніх шарів земноі атмосфери, ультрафіолетової радіащії Сонця і т. д. Головнаука вирішила відпуслетовоі радіаціі Сонця Кондратюка необхідні кошти, доручивши ї̈ редакцію компетентному вченому. Разом з тим,
Головнаукою була висловлена думка про надання Кондратюку можливості продовжувати працювати у вибраній ним галузі».

1926 р., жовтень-1927 р., квітень. Ю. В. Кондратюк працюе старшим механіком на будівництві елеватора на станції Ельхотово у Північній Осетіі. У Ельхотово Кондратюк зустрівсs 3 Горчаковим Петром Кириловичем, районним інженером контори «Хлібопродукт». Ознайомившись 3 характеристикою Кондратюка і оцінивши змістовність відповідей на професійні питання, Горчаков призначив Юрія Васильовича на посаду старшого механіка.

Включившись 3 притаманною йому енергією у роботу по будівництву, механізації і снергозабезпеченню Ельхотовського елеватора, Кондратюк удосконалив технологію будівельних робіт із застосуванням рухомої опалубки, вніс ряд раціоналізаторських пропозицій, почав конструювати новий, досконаліший ківш для подачі зерна на верхні поверхи елеваторів. А після роботи допомагав господарю квартири, продовжував роботу над рукописом, користуючись бібліотеками Владикавказу.

Перед Новим 1927 роком за дорученням адміністраціі фотограф, який приїхав з Владикавказу, сфотографував кращих робітників. Такий знімок (перший після гімназичних років) Юрій Васильович подарував пізніше К. Е. Ціолковському.

1927 р., квітень. Ю. В. Кондратюк відвідус Київ і Москву, зустрічається 3 професором В. П. Встчинкіним, обговорює 3 ним хід роботи над редагуванням і підготовкою до видання його книги «Завоювання міжпланетних просторів».

1927 р., 20 квітня-1930р., 30 серпня. Ю. В. Кондратюк працюс у Західному Сибіру та на Алтаї по експлуатації, ремонту, просктуванню і будівництву зернових сховищ i елеваторів, на різних посадах - від техніка і до помічника районного інженера крайової контори «Хлібобуд»,

Кондратюка призначають техніком $з$ будівництва зернового елеватора у районі Рубцовська (станція Велика Річка), але вже у серпні 1927 року його переводять у елеваторний відділ крайової контори «Хлібопродукт» техніком 3 механізації і реконструкції зернових складів, а 31928 року він - заступник головного інженера Сибірської крайконтори «ллібопродукт» (пізніше - «Сююзхліб»).

Тут він завершус роботу по вдосконаленню елеваторного ковша. 20 березня 1928 р. подас заявку на винахід «Ківш для 
елеватора-транспортераљ. Юрій Васильович будує найбільше у срітізованс дерев'яне зерносховище на 10000 т зерна. Ця споруда висотою $20 \mathrm{~m}$ і розмірами 60 м на $32 \mathrm{M}$, спроектована Кондратюком раніше, побудована 3 мінімальслия той час цвяхів, названа ним використанням дефіцитнх на той час цвяхв, названа Кондратюком «Мастодонтом». Він розробляє і створює засоби місцеві матеріали, будус зерносховище - елеватор 3 відвантажувальною естакадою.

1927 р., 4 грудня. Професор В. П. Ветчинкін пише передмову до книги «авоювання міжпланетних просторів».

1928 р., 4 червня. Відмова Головнауки видати книгу Ю. Кондрар., 4 червня. Відмова Головнауки виросторів.

1928 р., жовтень. Ю. В. Кондратюк пише другу передмову до своєі книти.

1929 р., січень. Виходить у світ книга Ю. В. Кондратюка «Завоювання міжпланетних просторів» під редакцією і 3 передмовою . Ветчинкіна і 3 двома передмовами автор профссора В. Л, Веня автора, тираж 2000 примірників).

Новосибірськ, видання автора, ти педмову, написану ше у

балиш Юрій Васильович помістив у книзі, крім передмови В. П. Ветчинкіна, також і свою другу передмову, написану у жовтні 1928 року, у якій йдеться про користь, яку

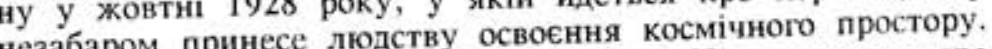
При цьому, не заперечуючи думку К. Е. Щіолковського про створення космічних поселень, робить основний акцент на

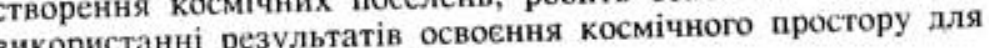
покрашення життя на Землі.

у цій книзі більш систематизовано викладені усі основні Ко Кондатюка у галузі космонавтики. До них, крім викладених раніше, можна віднести:

1. Використання проміжних баз на штучних або природс супутниках малої маси для дозаправки космічних коних супу ракетно-артилерійському постачанні цих баз.

2. Використання рідких компонентів ракетних палив для охолодження рубашки двигуна.

3. Використання бороводню і озону для підвищення теплового ефекту.

4. Обгрунтування багатоступеневих ракет 3 пропорційно зменшуваною масою.

5. Конструкція спускного апарата з аеродинамічним гальмуванням.

6. Використання крилатих ракет.
Ці та інші пропозиції не просто сформульовані, але і технічно і математично обгрунтовані.

Перш за все, він надіслав один примірник свосї книги К. Е. Ціолковському і один - В. П. Встчинкіну. На першій сторінці книги, яку він надіслав К. Е. Ціолковському, автор написав «3 повагою піонеру дослідження міжпланетних сполучень від автора. Ю. Кондратюк». Надіслав він книгу і у Ленінград Д. І. Перельману, а потім - М. О. Риніну та іншим інженерам, які працювали у цій галузі. Багато книжок було розповсюджено книжковими магазинами Москви i Ростова. Купували книгу і іноземці. Напевно, так і потрапив один 3 примірників у бібліотеку Конгресу США.

1929 р., лютий. Ю. Кондратюк отримав невеликий пакет. У ньому - невсликий лист (він, як усі листи, адресовані Кондратюку, не зберігся) і три брошури К. Е. Ціолковського: «Дослідження світового простору реактивними приладами», «Вибрані праці», «Відгуки».

На титульному листі першої книги - дарчий напис: «Шановному Юрію Кондратюку від автора. 1929 р. 15 люmого. К. Е. Ціолковський».

Незабаром прийшов лист від Д. І. Перельмана, який дякував за надіслану книгу, високо оцінював іiі і просив щс декілька примірників, оскільки роботою Кондратюка зацікавилися ленінградські вчені, серед них професор М. О. Ринін - один 3 організаторів Секції міжпланетних сполучень автор першої енциклопедичної праці 3 історії і теорії реактивного руху і космонавтики, В. В. Разумов, група інженерів на чолі 3 відомим ракетчиком М. I. Тихомировим, які об'сдналися у травні у відому Газодинамічну лабораторію (ГДЛ). У цю групу входив випускник ленінградського університету В. П. Глушко, майбутній академік. Пізніше він писав, що поряд 3 використанням праць К. Е. Ціолковського «з великим інтересом ми вивчали багату новими ідемми цікаву книгу Кондратюка».

1929 р., 1 травня. Ю. В. Кондратюк висилас професору М. О. Риніну лист і свою фотографію.

1929 р., кінсць-1930 р., початок. Ю. В. Кондратюк надсилає лист К. Е. Ціолковському, якого у 1930 р. той публікує у своїй книзі «Наукова етика».

1930 р., 30 березня. Ю. В. Кондратюк надсилає лист і фотографію К. Е. Ціолковському. Цей лист і фотографія зараз зберігаються в Архіві РАН у Москві.

1931 р., червень. Ю. В. Кондратюка і П. К. Горчакова направили у ПБК ОДПУ № 14. Тут Ю. В. Кондратюк проектує ряд споруд для Кузбасу. Спроектований ним залізобетонний 
копер вежного типу був утроє дешевшим за традиційний металсвий.

1931 р., 8 вересня. Ю. В. Кондратюк і П. К. Горчаков отримують авторське свідоцтво на винахід баштового ковша.

1931 р., жовтень-1933 р., квітень. Ю. В. Кондратюк і П. К. Горчаков публікують 4 статті по шахтобудівництву у «Горном журнале».

1932 р., початок. Професор М. О. Ринін публікує лист Ю. В. Кондратюка від 1 травня 1929 р. і його фотографію у книзі «Теорія космічного польоту».

1932 р., 28 березня. За рекомендацісю наркома Г. К. Орджонікідзе Ю. В. Кондратюк був достроково звільнений із заслання

1932 р., травснь. Ю. В. Кондратюк отримує запрошення Головенерго НКТП СРСР на конкурс по розробці проекту потужноі вітрослсктростанції в Криму, бере участь у ньому і займас перше місце.

Кондратюк подав у Центральну енергетичну раду (ЦЕР) НКТП свій проект, який він виконав практично за два місяці. А інститути, яким була доручена розробка, подали місяці. А інститути, яким була доруше. При цьому проект Кондратюка за техніко-економічними показниками був краКондатюкаючи відповіді, Кондратюк подав 13 грудня 1932 р. три заявки на винаходи, які стосуються ВЕС (слід відмітити, що до 1932 р. він ніколи не займався вітроснергетикою)

На початку травня Ю. В. Кондратюка і П. К. Горчакова викликали до начальника КБ-14 співробітники ОДПУ, і там оголосили, що за них клопотав Наркомтяжпром і тепер вони вільні люди i можуть піти 3 КБ, але це було 6 нс бажано. I до серпня 1932 р. Ю.В.Кондратюк і П. К. Горчаков залишалися у КБ-14. Однак посднувати напружену роботу в КБ 3 проектуванням ВЕС, нехай і ескізним, було важко.

1932 р., серпень-вересень. Ю. В. Кондратюк працює інженером у конторі «Союзмука".

1932 р., вересень-1933 р., квітень. Ю. В. Кондратюк працює інженером в Захсибенерго.

1932 р., грудень-1938р., вересень. Ю. В. Кондратюк у співавторстві отримує авторське свідоцтво на 3 винаходи в галузі вітротехніки.

1933 р., квітень-травень. Ю. В. Кондратюк на запрошення керівництва ГВРР відвідує відділ кадрів і лабораторію ГВРР, де зустрічасться з С. П. Корольовим та іншими співробітниками. Знаючи, що ГВРР знаходиться під пильним контролем спецорганів, і боячись перевірки біографічних даних,

\section{відхиляе запрошення перейти на роботу в ГВРР.}

*... Дізнавшись через Володимира Петровича Вєтчинкіна про приіззд Ю. В. Кондратюка у Москву, Корольов знайшов його і запросив у підвал на Садово-Спаській. Ю. В. Кондратюк приїхав уранці, i вони проговорили з Корольовим декілька годин. Корольов розумів, що перед ним - людина дивовижно обдарована, з розумом, який спроможний поєднати сучасну інженерію з фантастикою самою незвичайною Після смерті Цандера, така людина була йому конче потрібна. Корольов знав, що він уміє умовляти і використовував свій талант у той день максимально. У вироблену ним методику умовляння входили демонстрація техніки, стендові випробування, а по можливості навіть натурні старти прийом, подібний до «тиску могутністю техніки», особливо широко застосовувався Головним конструктором у 19501960-х роках, але і у ГВРР Корольов ним уже користувався. Він показував Кондратюку не тільки схеми й креслення, але і реальні ракети «у металів, водив у майстерні, умовив іхати на полігон в Нахабіні.

- Юрію Васильовичу, ви не повинні ні про що турбуватися, - «співав» Корольов.

- Клопотання про ваш перехід підпише сам Тухачевський. Я сам поговорю з Михайлом Миколайовичем. Потрібно визначити посаду... Ну, квартира - це само собою...

Знаючи Корольова, важко уявити собі, як витримав Кондратюк цю атаку. Він мовчав, посміхався у вуса, потім сказав тихо:

- Сергію Павловичу, це ніяк неможливо... Я зраджу людей, а це неможливо..

- Кого ви зрадите? - не зрозумів Корольов.

- Горчакова, Нікітіна... Ми проектусмо вітроенергетичну установку...

- Юрію Васильовичу! - вигукнув Корольов, він навіть почервонів від обурсння. - Та як ви можете порівнювати: політ у космічний простір й вітряк якийсь!

- О, ви не праві! Я्रкщо не рахувати Сонця, вітер друге джерело енсргіï для землян. Чистий, безшумний, невичерпний океан енергї! - очі Кондратюка горіли. - Ми поставимо вітрові установки у горах, на Крайній Півночі, ми отримасмо мільйони і мільярди кіловат-годин, не спалюючи ні крихти вугілля, ні краплі нафти! Ми збудуемо десятки вітрових Дніпрогесів! Невже ви не розумієте, як це важливо?

Корольов мовчав. Тепер стало ясно, чому він не може умовити Кондратюка: він наштовхнувся на людину ідеї. 
Якщо у людини є ідея, його неможливо збити з шляху ні квартирами у столиці, ні «ромбами» в петлицях. Кондратюк втрачений ного назавжди. Сергій Павлович миттсво якось поник, замовк. Кондратюк пішов. Корольов зразу перестав ним цікавитися, як кажуть у такому випадку, «викинув 3 голови». Була у нього така риса: людей, які не цікавилися його справою, він не засуджував, не критикував, просто вони для нього не існували. Більше з Кондратюком Корольов ніколи не зустрічався».

На відміну від Цандера, Кондратюк при всій своїй обдарованості, не був одержимим ракетником. Його полонили перспективи вітроенергетики. I тут він також дивився у майбутнє: у 1970-1980-х роках кількість теоретичних праць у цій галузі і реальних установок найрізноманітніших типів у світі збільшусться!

1933 р., 4 травня. Прийом Ю. В. Кондратюка і П. К. Горчакова наркомом Г. К. Орджонікідзе і направлення іх на роботу в Харків в Інститут промислової енергетики (УІПЕ) для розробки технічного проекту потужної Кримської ВЕС.

1933 р., червень-1934 р., січень. Ю. В. Кондратюк - науковий керівник розробки технічного проекту потужної Кримської ВЕС у Харкові.

1933 р., 30 литня. За підступним звинуваченням у шкідництві Ю. В. Кондратюк був заарештований. «Карна справа Ю. В. Кондратюка та інших виникла закономірно, як результат діючої на той час політики. В «Анкеті для заарештованих і затриманих з зарахуванням до ОДПУ, складеній 30 ваних і затриманих з зарахуванням до Оой Васильович повідомив про себе згадані вище анкетні дані.

Враховуючи істинну його біографію, Юрій Васильович прийняв правильну позицію. Якби слідство дізналося, що він не Кондратюк, а проживаючий під чужим прізвищем Шаргей Олександр Гнатович, 9 червня 1887 року народження, уроженець Полтави, мобілізованний у 1919-му в денікінську армію - не зносити б йому голови.

Такі відомості, безперечно, придали б особливого значення усій так званій «шкідницькій організації, були 6 доброю підмогою в руках фальсифікаторів, посилили б звинувачення не тільки проти Кондратюка, але і проти усіх його колег.

Він вибрав собі другорядну, незавидну роль мастильника механіка. Вигадана ж його батьківщина знаходилась тоді під Польщею і встановити істину було не так просто. Та слідство, напевно, не дуже цікавив рядовий механік з периферіі. Дивним здасться зараз інше: у справі зовсім немає що перед ними видатний вчений? Це у в Новосибірську у січні 1929 року, тобто за рік до арешту, вийшла його наукова праця «Завоювання міжпланетних просторів», яка отримала високу оцінку сучасників, як у країні, так i за їі межами. Невже не знали про його листування з К. Е. Ціолковским, В. П. Вєтчинкіним, М. О. Риніним, Я. І. Перельманом та іншими провідними вченими?

I ніхто не поцікавився ефективністю його винаходу, не призначив відповідної експертизи.

Справа закінчилася раптово, як і розпочалася. Ніхто навіть не склав звинувачувального висновку. Це підтвсрджує висновок про те, що «разслідуваня» було частиною політичної кампанії, кавалерійською атакою на інженерні кадри. 10 травня 1931 року постановою Колегії ОДПУ на підставі ст. 58-7 УК РРФСР Кондратюк, Куров, Бєляев і Аксьонов були ув'язнені у концтабір на три роки, а Горчаков i Лучинін - на п'ять років і відправлені до Сиблагу.

До місця ув'язнення Кондратюк відправився 3 діагнозом «нерастенія помірного ступеня». Позначилося нервове напруження. Подальша його доля, як і доля товаришів, визначилась тим, шо без інженерно-технічних спеціалістів країна не могла обходитися.

У період заслання Ю. В. Кондратюк працював у проектному бюро № 14 КБ ОДПУ при Кузбасбуді інженером-конструктором залізобетонних конструкцій.

1934 р., лютий. Ю. В. Кондратюк у Москві та Ленінграді захишас технічний проект КримВЕС i удруге зустрічається Г. К. Орджонікідзе.

1934 р., квітень. Проект КримВЕС було завершено. Він мав цілий ряд оригінальних рішень. Наприклад, акумулятор стислопо повітря для дублювання ВЕС у інтервали без вітру (нагнітання повітря за рахунок резерву потужностей ВЕС).

1934 р., жовтень. У Москві за розпорядженням Г. К. Орджонікідзе засновується контора по будівництву потужної КримВЕС.

1934 р., жовтень-1938 р., лютий. Ю. В. КондратюК керує розробкою робочого проекту КримВЕС.

1935 р., 3 березня. Ю. В. Кондратюк і П. К. Горчаков публікують статтю «Експертиза». У березні того ж року до робіт приеднався М. В. Нікітін (згодом він проектував і будував Останкінську вежу), 3 яким Ю. В. Кондратюк співробітничав ще у Сибіру. Консультував роботу В. П. Вєтчинкін.

1937 p., кінещь-1938 р., початок. Група провідних вчених і 
інженерів, куди входив і В. П. Ветчинкін, звернулася у Вищу атестаційну комісію щодо присвоєння Кондратюку вченого ступеня доктора технічних наук без захисту дисертації за стукен Олак ВАK, спираючись на характеристику від тресту Теплоенергобуд (куди входила проектнобудівельна контора), відмовила у цьому.

Якимось чином Кондратюк ознайомився 3 характеристикою, яку дав йому трест. В ній його проект безпідставно розгромлено i розкритиковано. Кондратюк звинувачений у розгомлевненості, нетерпимості до опонентів. I в кінці: «у суспільному житті тресту участі зовсім не бере. Політичного обличчя зовсім не виявлено.» Кондратюк знав від Вєтчинкіна обличия зовсім не виявлено Кондратюк знав від Ветииікан про розгром ленінградського і московського колективів ракетників. Він же розповів Юрію Васильовичу про історію авіаціі і космонавтики, про редактора друкованих творін К. Е. Ціолковського - Б. М. Воробйова, його чесність надійність. I Кондратюк, чекаючи нових ударів долі, передає йому на збереження свої рукописи. При цьому на прохання Б. М. Воробйова він ставить на них час ї написання. Так, у полтавсько-петроградських зошитах значитьсs 1916 рік. На рукописі «Тим, хто буде читати, щоб будувати!» - 19181919 pp. На третьому рукописі - 1920 і примітка: «Переписано i проредаговано у 1923-1924 рр.s Крім того, він передав Б. М. Воробйову два примірники машинописного передав Б. М. Воробиову два примірники . Борис Микитексту «Завовання міжпланетних просторів». Борис Микитович зберіг наукову спадшину Кондратюка і на початку 1960-x років передав ї до Інституту історії природознавства i техніки АН СРСР. А 3 того, що Кондратюк написав пізніше, більшість праць втрачена.

1938 р., лютий. Після трагічної загибелі Г. К. Орджонікідзе, Головенерго НКТП СРСР приймас рішення призупинити проектування і будівництво потужної КримВЕС і про перехіл на проектування і будівництво малопотужних вітроелектростанцій, для чого був створений Вітросектор при Теплослектропроекті (ТЕП).

1938 р., лютий-1939р., 15 вересня. Ю. В. Кондратюк працюс начальником техвідділу Вітросектору при ТЕП Головенерго НКТП СРСР по розробці малопотужних ВЕС.

1938 р., 2 липня. Ю. В. Кондратюк даруе свою книгу «Завоювання міжпланетних просторів» 3 дарчим написом інженеру Б. М. Воробйову - редактору і хранителю творчої спадшини К. Е. Ціолковського.

1938 р., 5 серпня. У звязку з розгромом колективів московських та ленінградських ракетчиків і арештами їніх провідних празберегти набутки 3 космічної техніки, щоб вони дійшли до людей і змогли принести користь у майбутньому. За порадою В. П. Ветчинкіна для реалізації цісї мети був обраний Б. М. Воробйов..

Перед передачею паперів Б. М. Воробйову Ю. В. Кондратюк на обкладинці, у яку вшив чотири полтавсько-петроградські зошити, написав: «1916 р. 5/VII.38. Юр. Кондратюк».

1938 р., 5 вересня. Ю. В. Кондратюк направляс свою книч «авоювання міжпланетних просторів» 3 дарчим написом у Калугу в дім-музей К. Е. Ціолковського для експонування у музеі.

1939 р., жовтень-листопад. Ю. В. Кондратюк і П. К. Горчаков публікують статтю «Основні характеристики і перспективи вітроенергетики» у журналі «Електричні станціі».

1939 р., 15 вересня. Засновусться Проектно-експериментальна контора по вітроелектричних станціях (ПЕКВЕС) при ТЕП Головенерго НКЕП СРСР.

1939 р., 15 вересня-1941 р., 6 липня. Ю. В. Кондратюк працює начальником проектного відділу ПЕКВЕС і керус проектуванням малопотужних вітроелектростанцій ВЕС 2-Д-20 на $100 \mathrm{\kappa BT}$ i ВЕC 2-Д-30 на $250 \mathrm{kBт}$. Весною 1941 року Ю. В. Кондратюк готувався до підйому, установки і наступного випробування на підмосковному полігоні ВЕС 2-Д-20 потужністю аж... 100 кВт. Ця робота також супроводжувалася підготовкою і публікацісю наукових статей, розробкою винаходів і оформленням заявок на видачу авторських свідоцтв.

1941 р., 21 червня. Ю. В. Кондр:ттюку виповнилося 44 роки (за документами - 4I). Він н святкував дня наролження, цілковито поринувши у роботу на полігоні. Але усе перекреслила війна. Наступ німецько-фашистських загарбників поглинув більшість території країни. Намітилась загроза для столиці. Поступила вказівка - вежу ВЕС не піднімати, щоб не створювати орієнтирів для фашистської авіації, а роботи по ВЕС 2-Д-20 згорнути.

1941 р., 6 липня. Ю. В. Кондратюк відправляється добровольцем у дивізію народного ополчення Київського району м. Москви і зараховується червоноармійцем роти зв'язку стрілецького полку. Ця дивізія одразу ж відправляеться на фронт.

1941 р., 30 вересня. Б. I. Романенко востаннє зустрічає Ю. В. Кондратюка поряд 3 бліндажем штабу стрілецького полку у лісі, що на південний захід від села Барсуки Кіровського району Калузької області. 
1942 p., лютий. Телефоніст, зараз полковник у відставці, Сергій Кирилович Дергунов воював разом з Ю. В. Кондратюком.

1942 р., 23 лютого. Рядовий зв'язківець Ю. В. Кондратюк загинув на Орловській землі (біля Кривцовського меморіалу) у Волховському районі. Тривалий час вважали, що Ю. В. Кондратюк загинув 3 жовтня 1941 року. Але пізніше були знайдені його листи (листівки), датовані 5 грудня 1941 року і 2 січнs 1942 року і люди, які зустрічалися 3 Юрієм Кондратюком значно пізніше.

Таким чином, про завершення життєвого шляху Ю. В. Кондратюка нічого невідомо. ЯК часто буває у таких випадках, невідомість служить грунтом для різних сенсацій. Деякі стверджували, що частина рукописів Ю. В. Кондратюка потрапила до німецького ракетчика Вернера фон Брауна. ка потрапила до німецького ракетия писали), що якийсь Ю. В. Кондратюк працював у фон Брауна. Однак ніяких . доказів цих версіи ні комісія радянських ні західні спецслужби не виявили.

1947 р. Виходить у світ друге видання книги Ю. В. Кондратюка «Завоювання міжпланетних просторів» у виданні Оборонгізу тиражем 5000 примірників.

1964 р. Виходить у світ стаття Б. М. Воробйова і В. Н. Тростнікова Про нсопубліковану роботу Ю. В. Кондратюка "Тим, хто буде читати, щоб будувати"». Виходить у світ трете видання книги Ю. В. Кондратюка «Завоювання міжпланетних просторів», 3 першою повною публікацією роботи \&Тим, хто буде читати, щоб будувати».

1970 р., 26 березня. Судова колегія карних справ Верховного суду РРФСР повністю реабілітувала Ю. В. Кондратюка.

975 р. Тетяна Йосипівна Маркевич робить письмове зізнання Б. I. Романенку про обставини зміни імені Олександрои Шаргеєм.

977 р., квітень-травень. Ніна Гнатівна Шаргей дає письмові показання Комісії ЦК КПУ про обставини зміни імені і1 братом Олександром Шаргесм і пише 18 квітня лист до віце-президента АН УРСР Г. С. Писаренка: «Хочу розказати иро те, що мені відомо про обставини зміни імені, по батькові і прізвища мого брата Олександра Гнатовича Шаргея (Юрія Васильовича Кондратюка). Раніше я не розпе 3 мене слово мовчати. Тenep я наважилася розповісти все, з мене сл бо в наукових організащіях виявлено великий що знаю, бо в наукових організац до біографії брата, і навколо факту зміни прізвища виникає немало пліток. Я вважаю, шо причиною зміни прізвища братом О. Г. Шаргеєм було прагнення уникнути серйозних наслідків, пов'язаних 3 його службою у білій арміï...

Як мені говорили, мама, приблизно в 1920-1922 pp., для брата дістала документи Юрія Васильовича Кондратюка, молодої людини приблизно одного з ним віку (1900 p. народж.), який помер незадовго до цього. У моєі мами бул: давня добра знайома Віра Григорівна Тучапська, викладачк. київської школи № 50 (Комерційний пров.), У цій школі викладав Володимир Васильович Кондратюк, старший брат покійного Юрія, який був у добрих стосунках з В. Г. Тучапською. На ії прохання В. В. Кондратюк передав через неі документи покійного брата моїй мамі. Наскільки можу згадати 3 пізніших розмов, цей документ був профспілковим квитком чи якимось іншим посвідченням особи. Документ передали в Малу Віску через Лашинських.

В. В. Кондратюка я знала особисто, тому що в 19231925 pp. навчалася у школі № 50 , де він викладав. Тоді $\mathrm{g}$ зовсім не знала про його роль у долі мого брата. Востаннє я зустріла В. В. Кондратюка пригніченого i розгубленого, i розмовляла 3 ним, на вулиці окупованого німцями Кисва наприкінці 1941 р... Що я ще пам'ятаю про брата? Він був старшим за мене на 13 років. Тому мої дитячі спогади про нього дуже нсвиразні і уривчасті. Знаю, що він весь час до Вітчизняної війни допомагав нам з мамою матеріально».

1977 р., квітень-травень. Працюе Комісія ЦК КПУ, яка за наданими багаторічними пошуковими матеріалами Б. I. Романенка і показаннями Т. Й. Маркевич і Н. Г. Шаргей визнала відсутність криміналу у самому процесі зміни імені Олександром Шаргесм i винесла рішення відновити i увічнити добре ім'я видатного вченого.

Така складна біографія вченого-першопрохідця, косміста, гуманіста О. Г. Шаргея-Ю. В. Кондратюка, який у 17 років (1914 р.) в чотирьох непримітних школярських зошитах виклав згусток відкриттів і цікавих пропозицій 3 теорії міжпланетних польотів.

За рішенням 28-ї сесії Генеральної конференції ЮНЕСКО 21 червня 1997 р. увесь світ відзначас пам'ятну дату - 100-річчя 3 дня народження українського вченого i дослідника, піонера космічної техніки Юрія Кондратюка (О. Шаргея). 


\section{6. ЛIТЕРАТУРА}

Голованов Я. К. Королев С. П. Факты и мифы. - М.: Наука, 1994.

Граб В. И., Супруненко А. Б. Дело № 10558. Ю. В. Кондратюк и другие. - Полтава: Метоп, 1992.

Даценко А. В. Я полечу туди... - Харків: Прапор, 1989.

До 100-річчя 3 дня народження Ю. В. Кондратюка // Космічна наука і технологія. Додаток до журналу. $-1995 .-1$, № 1.-24 c. Ивашенко А. Выше элеватора - Луна // Известия.-19 июня (№ 170).

Кондратюк Ю. В. Завоевание межпланетных пространств. - Новосибирск, 1929.-Изд. автора.

Кондратюк Ю. В. Полтавско-петроградская рукопись. - 1916.104 с.-Рукопись. Автограф (Институт истории и естествознания и техники РАН. Фонд Ю. В. Кондратюка).

Космічні і земні орбіти Ю. В. Кондратюка (О. Г. Шаргея) / Упор.

Б. В. Журахович, А. П. Завалішин, О. О. Негода, А. І. Стегній.

- Дніпропетровськ: Січ, 1996.-408 с.

Космонавтика. Сов. энциклопедия. - М., 1985.

Космонавтика СССР. - М.: Машиностроение, ПІланета, 1987.$496 \mathrm{c}$.

Пионеры ракетной техники. Кибальчич, Ціолковский, Цандер, Кондратюк: Избр. тр. - М.: Наука, 1964.

Романенко Б. И. Звезда Ю. В. Кондратюка // Наука в России.1995.-№ 2.

Романенко Б. И. Юрий Васильевич Кондратюк. - М.: Знание, 1988.

Смирнова Н. Где погиб Кондратюк? // Весть.-1966.-26 ноября. Украинский советский энщиклопедический словарь: В $3-x$ т. Киев: Глав. ред. УСЭ, 1988. 